\title{
Licensing Double Negation in NC and non-NC languages
}

\author{
Genoveva Puskás
}

Received: 2 September 2010 / Accepted: 12 December 2011 / Published online: 19 January 2012

(C) Springer Science+Business Media B.V. 2012

\begin{abstract}
The paper proposes a syntactic and semantic analysis of Double Negation (DN). It is shown that there are two types of DN. Strong DN is the result of a Focus construction that involves a polar reading triggered by a Verum Focus; Weak DN, on the other hand, arises when the corresponding n-word is marked as a Contrastive Topic and introduces weak (i.e. non-exclusive) alternatives. The paper discusses the occurrence of these two kinds of DN in two types of languages, which feature different negative strategies. While Hungarian is a strict NC language with non-negative n-words and an obligatory negative marker, English and German are non-NC languages, with negative n-words that can function on their own. It is shown that both strong DN and weak DN occur in each of these languages. However, the mechanisms that license $\mathrm{n}$-words contributing the DN reading are different, due to the differences in the nature of the n-words and in the discourse-functional behavior of the languages in question.
\end{abstract}

\section{Goal of the paper}

Until recently, little real attention has been paid to the phenomenon of double negation. Much of what the literature says amounts to observations. However, it is generally recognized that the phenomenon does exist, and moreover, it coexists with negative concord in some languages (see e.g. Zeijlstra 2004). It has been described in some detail for French (Corblin 1996; Corblin \& Tovena 2003) with observations as to the "special" contexts in which it occurs. De Swart is the first to dedicate a whole chapter to the phenomenon (de Swart 2010). She also mentions that double negation needs special contexts. Although her approach gives a reasoned account of the phenomenon, it is set in bidirectional Optimality Theory, a framework in which

G. Puskás $(\bowtie)$

Département de Linguistique, Faculté des Lettres, University of Geneva, 5, rue de Candolle, 1204 Geneva, Switzerland

e-mail: genoveva.puskas@unige.ch 
grammatical differences are modeled as constraint re-ranking, and which is thus incompatible with a minimalist approach.

The goal of the paper is to give an account of double negation (henceforth DN) in a minimalist framework, taking as a stance that if the model it proposes is an adequate representation of linguistic knowledge, it should also be able to handle the rather tricky question of double negation for which native speakers have clear intuitions. One of the fundamental claims of a minimalist approach is that syntactic structures are identical cross-linguistically, a claim that leaves much of the burden of variation to the "periphery": "The primary [task] is to show that the apparent richness and diversity of linguistic phenomena is illusory and epiphenomenal, the result of interaction of fixed principles under slightly varying conditions" (Chomsky 1995: 8). Such an approach has been underlying much of the research on negation. It has led to, among other things, a debate about the nature of negative expressions-socalled n-words, following Laka's (1990) terminology. One line of thought proposes that n-words occurring in Negative Concord (henceforth NC) languages are intrinsically negative (cf. Haegeman 1995; Haegeman \& Zanuttini 1996; Zanuttini 1997; Mathieu 2001; Corblin \& Tovena 2003; Baunaz 2008). Another one claims that $\mathrm{n}$-words in languages that require the presence of a negative marker (whether in a strict relation, as in Greek or Hungarian, or in non-strict relations, as in Italian) do not have independent negative force (cf. Giannakidou 2000; Puskás 2002; Surányi 2003, 2006 for Hungarian; Péters 2001; Déprez 2003; Rooryck 2008 for French). Clearly, the question of DN arises when one adopts the latter view: How does a DN reading arise at all if $n$-words do not provide negative content? In this paper, I address this question and provide an answer that builds on the semantics, the syntax, and the pragmatics of DN.

I adopt the view, described above, that languages exhibiting $\mathrm{NC}$ have non-negative n-words, in that they cannot independently convey a negative meaning. Thus the distinction between $\mathrm{NC}$ and non-NC languages resides in the feature composition of the relevant elements (cf. Zeijlstra 2004). I propose, based on the observation that DN occurs in "special" contexts, that DN contexts are associated with specific semantic properties and also with specific syntactic environments. Such contexts enable nonnegative n-words to be licensed independently from (or at least on top of) regular sentential negation, thus yielding the DN readings.

The facts that have launched this inquiry are the following. Hungarian is an NC language, but nevertheless displays DN phenomena. Further investigation has revealed that DN actually occurs in very precise linguistic contexts, which I illustrate here.

In a strict NC language like Hungarian, the co-occurrence of the negative marker nem and one n-word can only result in simple negation, independently of the position of the n-word:

a. Nem vettem semmit. $^{1}$

NEG bought-1s n-thing-ACC

'I didn't buy anything.'

\footnotetext{
${ }^{1}$ The Hungarian glosses contain the following abbreviations: NOM for nominative, ACC for accusative, DAT for dative, INST for instrumental, DELAT for delative and PART for the verbal particle.
} 
b. SEMMIT nem vettem.

n-thing-ACC NEG bought-1s

'I didn't buy ANYTHING.'

c. ${ }^{\#}$ Semmit $_{\mathrm{CT}}$ nem vettem.

n-thing-ACC NEG bought-1s

Whereas (1a) expresses a neutral negative statement, (1b) can be used to emphasize the n-word, which will then occur in the dedicated Focus position (small caps). However, the sentence cannot have a DN reading. Sentence (1c), where the n-word occupies a let-peripheral Contrastive Topic position (sub-index CT), turns out to be rather awkward as single negation. But again, the DN reading is totally excluded.

The DN reading may arise when the sentence contains two n-words. (2a) shows a case of regular $\mathrm{NC}$, with the negative marker nem associated with two co-occurring n-words. (2b) shows the same negative marker and the same n-words. However, in (2b) one of the n-words appears in the dedicated Focus position (small caps), and the reading is necessarily a DN reading. (2c) illustrates another, rather intriguing pattern, where one n-word occurs in a pre-verbal n-word position, and the other one occupies the left-peripheral Contrastive Topic position (sub-index CT). This pattern also yields a DN reading:
a. Senki
nem vett
semmit.
n-person-NOM NEG bought-3s n-thing-ACC
'Nobody bought anything.'
b. SENKI nem vett semmit.
n-person-NOM NEG bought-3s n-thing-ACC
'NOBODY bought nothing.'

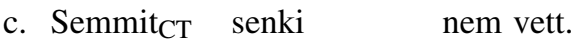
n-thing-ACC n-person-NOM NEG bought-3s
'Nothing, nobody bought.'

Although both (2b) and (2c) are DN sentences, they differ in several respects. First, they differ in their syntactic structure. As will become clear below, the Focus position and the Contrastive Topic position are syntactically identified and constrained positions in Hungarian. But I will also claim that they differ in their interpretation. (2b) is felicitous as the denial of a previous utterance or as a complete answer to a relevant wh-question, and it invokes a polar type of alternative. However, (2c) cannot be used under the same circumstances as (2b). Rather, (2c) is felicitous as a denial with respect to the element in the CT position, and invokes a set of possible alternatives to it.

On the basis of these observations, I argue that there are two kinds of strategies for DN. Although both are dependent negation (in that they feed on a primary sentential expression of negation), I distinguish between them on the basis of their respective negative contribution and their contribution to the information structure of the expression in which they appear. The first type is argued to contribute a DN reading that realizes the negation of the whole clause on which it builds, and it expresses a wide-scope type of negation. I have labeled it strong $D N$ as it triggers a unique, polar alternative to the assertion expressed in the clause. In Hungarian, it is typically 
triggered by the presence of an n-word in the Focus position, as illustrated in (2b). The second type contributes a reading that negates a part of the clause on which it depends; it is an instance of narrow-scope negation. I have labeled it weak $D N$, as its negative contribution does not built on exhaustivity or polarity, but appears to be one of several weak alternatives within the context of the sentence in which it appears. In Hungarian, it occurs when the relevant n-word occupies a left-peripheral Contrastive Topic position, as shown in (2c). In a language with a richly articulated left periphery, the different strategies for DN are encoded in different syntactic structures, and rely on different licensing mechanisms.

In languages that exhibit $\mathrm{NC}$, the non-negative n-words must be licensed by some negative element on which they feed. I show that the two kinds of DN necessarily require two different licensors. Hungarian serves to exemplify this behavior. In languages without $\mathrm{NC}$, the standard assumption is that n-words are independently licensed. They do not rely on an additional licensor to contribute the DN reading. Typically, English and German belong to this category. However, I argue that in these languages, the different types of DN are triggered in relation to the same manifestations of information structure as in NC languages.

The paper is organized as follows. Section 2 gives a brief overview of the "special contexts" in which DN appears, in terms of both their meaning as well as their prosody. Section 3 discusses the phenomenon of DN in a strict NC language, namely Hungarian. It is shown that the relevant contexts provide a Focus and a Contrastive Topic reading. These have been analyzed in Hungarian as associated with distinct syntactic phenomena. I therefore show that DN can only be licensed in a Focus or a Contrastive Topic environment and, as such, it must undergo the relevant syntactic treatment. Section 4 looks at non-NC languages, that is, languages in which the standard assumption is that n-expressions are intrinsically negative. Although the question of independent licensing does not arise, it is observed that the same two types of DN can be triggered and the same discursive conditions apply, with very clear restrictions. Section 5 concludes the paper.

\section{What is DN?}

A rather standard claim about (sentential) negation is that it involves a unary operator that operates on the truth value of the proposition. From this point of view, DN seems a redundant operation. Consider the sentence in (3) below.

(3) Lenny likes linguistics.

The logical form of the corresponding negative sentence (i.e. Lenny does not like linguistics) will be:

(4) $\neg$ LIKE (lenny, linguistics)

Under a standard view, "double negation" will logically invert the polarity of the negated sentence and cancel the original negation, thus converting the sentence back to its non-negated meaning as in (3):

$$
\neg(\neg \text { LIKE (lenny, linguistics)) }
$$


However, it has been claimed that DN has very different effects (see e.g. Horn 1991). In this paper, I claim that these effects can be attributed to the presence of one of two kinds of DN. The first kind, probably the most straightforward one, results in some corrective effect at the level of the whole utterance. The presence of DN triggers a unique, polar alternative to the assertion expressed in the clause and is a case of strong $D N$ (see Sect. 1 above). Consider the following negative sentence:

(6) Lenny likes nothing.

The sentence in (6) can be negated, as in (7):

(7) Lenny does NOT like nothing.

Sentence (7) is a case of strong DN, and is felicitous under several conditions. First, it must bear a specific intonation pattern (hence the small caps), to which I come back below. And second, it must come as a correction to a previous utterance, such as (6) above. As such, it is interpreted as "it is not the case that Lenny likes nothing". This type of corrective double negation is parallel to the well-known metalinguistic (simple) negation (see Ducrot 1972; Horn 1989).

Horn argues that metalinguistic negation is used not as the negation of a proposition but as "an objection to a previous utterance, on any grounds whatever" (Horn 1989:362). This is what confers to it its corrective status. The corrective form may then be juxtaposed with the negative segment it corrects:

(8) It isn't hot-it's scalding.

(Horn 1989:404)

Example (8) is an illustration of metalinguistic negation bearing on the clause: the contrast involves the whole clause, and may be explicitly rendered as not [it is hot].

The same kind of wide scope corrective interpretation appears with strong DN. Consider (9) first:

(9) Context: Lenny went shopping. Speaker A claims that, despite Lenny's wellknown greed, he didn't buy anything. Speaker B may felicitously respond as follows:

Speaker B: Lenny did NOT buy nothing-he bought up the whole town!

In (9), the corrective segment, which is juxtaposed, comes as reinforcement of a negative sentence containing the negative constituent nothing. The DN itself is triggered by the presence of the negative marker not, which introduces a sharp contrast. It inverts the polarity of the clause and strongly contrasts it with a previous utterance/presupposition.

The English examples above may lead to the simplistic view that strong DN results from the combination of a negative expression, such as nothing, with the negative element not. However, it seems that the same kind of strong corrective DN may arise when the sentence contains two negative expressions:

(10) Context: Lenny went shopping with a few friends. Speaker A remarks that some of Lenny's friends are rather tight with their money, and are all bound to have come back empty-handed. Speaker B can felicitously respond as follows:

Speaker B: NOBODY bought nothing! 
In (10), DN is contributed by the second negative expression, nobody, which triggers a strong corrective effect. Crucially, this type of DN is associated with a strong primary stress that bears an intonation of the kind $\mathrm{H}^{*} \mathrm{~L}$. This type of DN is attested in other languages as well, such as in Italian, a "non-strict" NC language, or Greek, a "strict NC" language:

a. Non HO detto niente.

(Italian)

NEG have-I said nothing

'I haven't said nothing.'

(A. Cardinaletti p.c.)

b. KANENAS dhen idhe tipota.

(Greek)

n-person not saw-3sG n-thing

'Nobody saw nothing.' (= Everybody saw something.)

In the Italian example (11a), a DN reading is possible in the presence of the sentential negation marker non and a post-verbal n-word. In this case, as observed by A. Cardinaletti (p.c.), the sentence must contain a focus, possibly on the finite auxiliary or verb. Greek also exhibits DN readings, as in example (11b) (provided by a reviewer). In this case, the first n-word bears an emphatic stress, but the second one is non-emphatic. As will be discussed in detail in the next section, such a DN reading, which is associated with a strong emphatic stress and a corrective reading bearing on the whole utterance, is also available in Hungarian.

However, DN can also yield milder corrective effects. As observed in Jespersen (1924), the two negative elements that occur in DN can combine in a more subtle way. Comparing a DN utterance with its positive counterpart, Jespersen notes that "the longer expression is always weaker; [it] ... implies a hesitation which is absent from the blunt, outspoken [expression]" (Jespersen 1924:332). Jespersen thus characterizes $\mathrm{DN}$ as a means of weakening the import of an utterance. This is the version of DN that I have labeled weak DN. Consider the following example:

(12) Context: Lenny went shopping. This time, Speaker A claims that due to Lenny's rather difficult financial situation, he bought nothing. Speaker B may answer:

Speaker B: Lenny did not buy nothing, (just nothing really expensive).

Speaker B's response in example (12) also comes as a correction of A's utterance. However, it can also simultaneously provide an alternative (nothing really expensive), which appears as one possible alternative to nothing. The hearer thus infers that Lenny bought something, and constructs the implicature that there are several alternatives in the context. In this case, I will propose that the DN is triggered by the presence of narrow-scope negation. It can be paraphrased as [he bought [not [nothing]].

Weak $\mathrm{DN}$ is similar to concessive single negation as discussed in Horn:

$$
\begin{aligned}
& \text { a. It isn't hot, but scalding. } \\
& \text { b. \# It isn't hot, but it's scalding. }
\end{aligned}
$$


Example (13a) shows that the correction bears on the constituent hot, since the corrective form juxtaposes it with another adjective. In this case, Horn's metalinguistic negation is narrow-scope negation, and may be schematized as It is [not hot]. Thus, DN is not limited to wide-scope negation. Some instances of VP-negation also appear to have a corrective interpretation (see also Giannakidou 1998 on constituent negation as metalinguistic negation). ${ }^{2}$

The 'weakening' approach is adopted and developed in Horn (1991). The author observes that, contrary to logical predictions, the negation of contradictory opposites does not produce total redundancies, so that 'not odd' is somehow different from 'even'. Horn identifies a cluster of properties as typical of the DN phenomena he examines, of which the most salient are (i) loophole, and (ii) concession.

Property (i) is based on the observation that the resort to DN is motivated by a desire to leave oneself a loophole, in order to get out of a difficult situation. Horn's example (7a), given in (14) below, illustrates the point:

(14) I do not pretend to be a pure bachelor. I was married for five years, and it was, to use a cowardly double negative, not an unhappy experience.

(Phillip Lopate, introduction to Bachelorhood)

Horn claims that, "with the conscious or tacit goal of loophole-procurement, the speaker describes something as not unX in a context in which it would be unfair, unwise, or impolitic to describe that entity as X." (Horn 1991:84).

Property (ii) expresses the idea that DN may be appropriate in situations where the utterance asserts a state of affairs that is different from what might have been expected: “... the positive evaluation associated with the doubly negated adjective represents a concession, wrung out reluctantly from the source of the left-handed not un- compliment." (Horn 1991:84). This is illustrated in example (15) below (Horn 1991:84):

(15) I wish Mr. Starr had been kinder to California's Progressives. He is certainly not unjust in pointing out their limitations, but it seems to me that we do not recognize all that the pre-WWI reform movements in this country accomplished ...

(Naomi Bliven, New Yorker 8/12/85)

It appears from the examples given here that the contrast triggered by $\mathrm{DN}$ is not as strong as in the previous cases. The presence of the DN marker does not trigger a unique, polar, contrastive alternative, but rather several weaker alternatives. To illustrate this point, let us come back to example (14). The DN does indeed come as a correction to some - contextually triggered-assertion that marriage was an unhappy experience. However, the "loophole" interpretation seems to suggest that the DN does not only come as a mere correction of the above assertion, but also triggers weaker alternatives, such as the implicit assertion that the marriage, although not an unhappy experience, was not happy altogether, and could have ranged over possible degrees of satisfaction.

\footnotetext{
${ }^{2}$ Note that Giannakidou (1998) claims that metalinguistic negation and constituent negation are very similar: "First, both express negation "narrower" than the sentential negation: constituent/metalinguistic negation does not take sentential scope. Second, they are both corrective." (Giannakidou 1998:50)
} 
Although most of the examples discussed by these authors involve incorporated negation, I claim that negative expressions can contribute DN in the same way, as illustrated in (12) above. Notice also that (12) involves one negative expression and the negative element not.

As opposed to the previous cases, weak DN is thus a correction to some part of the utterance. It contributes an opposition between the part in question and several possible alternatives. It is also subject to special intonation constraints, in that one of the negative expressions appears with a fall and rise, which I signal with the diacritic $\sqrt{ }$. Zanuttini notes that "when (a) a primary stress is on niente and secondary stress on the finite verb ho, (b) a pause separates the two, and (c) niente has a fall-rise on it, then the reading is that of a double negation" (Zanuttini 1991:130): ${ }^{3}$

(16) Proprio $\sqrt{ }$ niente, non ho detto.

absolutely nothing, NEG I-have said

'I haven't said nothing.'

(Zanuttini 1991)

The same kind of fall-rise pattern occurs in weak DN in Hungarian, to be discussed in the next section.

$\mathrm{DN}$ as a corrective phenomenon builds on the negation of a relevant constituentbe it phrasal or sentential. I will show that the strong-or polar-interpretation obtains via the Focus-presupposition strategy; the weaker version, although also involving a focusing strategy, depends on the availability of an n-word as a Contrastive Topic. Weak DN resorts to a different kind of focusing, which introduces several non-exclusive alternatives. I will argue that each type of DN contributes a particular semantic content, and is encoded in distinct syntactic functions. I propose that what Horn labeled metalinguistic negation is not, per se, pragmatic in essence. The specificities of the DN mechanism are anchored in particular syntactic constructions, which are associated with given semantic properties. However, both Focus and Contrastive Topics call for various types of alternatives, and it is the context itself that determines the set and range of alternatives. What is then "metalinguistic" is not the mechanism, but the ultimate interpretation of the contrasts triggered by the presence of negative elements. Therefore, an analysis of DN relies strongly on a division of labor, which assigns to syntax, semantics and pragmatics their respective tasks as contributors to the phenomenon. This paper aims at exploring these contributions.

\section{DN in Hungarian 4}

In this section, we will examine in detail the occurrence of DN in a strict NC language. In Hungarian, as in other languages, a DN reading requires a special intonation. In standard negation, which by default yields an NC reading, the n-words all

\footnotetext{
${ }^{3}$ It should be noted that although Zanuttini refers to a "rise and a fall", the manuscript contains a handdrawn contour that shows a slight rise, followed by a fall, followed by a slight rise at the end of the phrase. This is reminiscent of Jackendoff's (1972) "hat contour", and corresponds to what has been described as a "fall-rise" in other cases (see e.g. Jacobs 1996; Büring 1999).

${ }^{4}$ This section has much benefited from discussions with Chris Piñón and Maribel Romero, whom I wish to thank warmly. Needless to say, any error or confusion is totally mine.
} 
bear a uniform stress (17a), which will be signaled throughout with the diacritic". 5 DN arises when different $n$-words bear different stress (17b): ${ }^{6}$

a. Kolozs "senkinek nem mondott "semmit.

K.-NOM n-person-DAT NEG said-3s n-thing-ACC

'Kolozs didn't say anything to anybody.' (NC)

b. Kolozs SENKINEK nem mondott semmit.

K.-NOM n-person-DAT NEG said-3s n-thing-ACC

'Kolozs said nothing to NOBODY.' (DN)

In (17a) the two n-words both have the default emphatic stress (as indicated by the diacritic"). They combine to form one negation with the negative marker nem at the sentential level. Sentence (17b), which is interpreted as DN, differs from (17a) in that the first n-word bears a strong primary stress, signaled by small caps, whereas the second one, semmit 'nothing-acc', appears without emphatic stress. Rather, it is pronounced with a steady lowering or flat intonation.

The same kind of minimal pair is also possible with several n-words in a preverbal position. Hungarian can stack n-words in the left periphery, in a quantifier-related position. When both quantifiers bear identical stress, they enter into NC (18a). But a DN reading is also available, provided that the first negative quantifier is pronounced with a fall-rise (18b):
a. Kolozs "semmit "senkinek nem mondott.
K.-NOM n-thing-ACC n-person-DAT NEG said-3s
'Kolozs didn't say anything to anybody.' (NC)
b. Kolozs $\sqrt{ }$ semmit "senkinek nem mondott. K.-NOM n-thing-ACC n-person-DAT NEG said-3s

'There is nothing that Kolozs said to nobody.' (DN)

As in the previous pair, the difference in interpretation is triggered by a change in the intonational pattern. Whereas (18a) is interpreted as a NC, (18b) is a case of DN. The interpretation of (18b) is not exactly identical to that of (17b), though. Example (17b) is interpreted as a strong polar correction to some previous negative utterance, and can be paraphrased as 'It is not the case that Kolozs said nothing to somebody' (not $[K$. said nothing to $p($ erson) $]$ ). It illustrates strong DN. Sentence (18b), on the other hand, provides a weak correction. The correction bears on the n-word semmit 'nothing', which is interpreted as one of several possible alternatives in the set of

\footnotetext{
${ }^{5}$ This stress is less prominent than the primary stress on a focused constituent, in that its pitch is lower, it is not as loud and induces less lengthening than the focus stress. In sentences involving Negative Concord, not only the first, preverbal n-word, but all other negative elements which enter into NC bear this stress: "neg-phrases are always stressed in post-verbal position: we have taken this throughout as indicating LF movement." (Brody 1990:224)

${ }^{6}$ The data under discussion in this paper are based on rather subtle judgments. Thus I have found variations with respect to the acceptability/interpretation of different DN constructions. It should be noted that some of the Hungarian data given here were spontaneously provided by native speakers, other examples have been tested on informants, and some interpretations rely on my own judgments.
} 
things that could have been said by Kolozs. It can be paraphrased as 'there is no thing that Kolozs said to nobody' (K. said [not thing] to nobody). Thus it illustrates weak $\mathrm{DN}^{7}$

We will now examine each DN type. Section 3.1 gives a brief introduction of negation in Hungarian, Sect. 3.2 discusses strong DN and Sect. 3.3 is devoted to the analysis of weak DN.

\subsection{Negation in Hungarian}

Hungarian negative sentences come with a negative marker nem. $\mathrm{N}$-words, whether in preverbal or post-verbal position, obligatorily appear with the negative marker:

$$
\begin{aligned}
& \text { a. Senki *(nem) ismeri Rékát. } \\
& \text { N-person-NOM NEG know-3s Réka-ACC } \\
& \text { 'Nobody knows Réka.' } \\
& \text { b. Réka *(nem) ismer senkit. } \\
& \text { Réka-NOM NEG know-3s n-person-ACC } \\
& \text { 'Réka does not know anybody.' }
\end{aligned}
$$

I assume that nem is the realization of a negative head, which encodes the sentential negative operator. As mentioned above, Hungarian is a NC language. This means that multiple n-words in the sentence contribute one negative force. ${ }^{8}$ In Hungarian, these n-words can appear post-verbally (20a), pre-verbally (20b), or be distributed to either side of the verb (20c):
a. Réka nem mondott semmit senkinek. Réka-NOM NEG said-3s n-thing-ACC n-person-DAT 'Réka didn't say anything to anybody.'
b. Réka senkinek semmit nem mondott. Réka-NOM n-person-DAT n-thing-ACC NEG said-3s
c. Réka semmit nem mondott senkinek.
Réka-NOM n-thing-ACC NEG said-3s n-person-DAT

Surányi (2006) argues that Hungarian n-words are ambiguous between a universally quantified and an indefinite reading. The author convincingly shows that while n-words in post-verbal position may be indefinites or universally quantified elements,

\footnotetext{
${ }^{7}$ Among the various possible patterns, we can also mention the one given below: for some speakers a single negative quantifier in a preverbal position may also yield a DN reading, again provided that it is pronounced with the same $\mathrm{L} * \mathrm{H}$ intonation. A second n-word occurs post-verbally:

(i) $\sqrt{ }$ Semmirôl "nem beszéltem senkivel.

n-thing-DELAT NEG-spoke-1s n-person-INSTR

'I didn't talk to anybody about nothing'

In this case, though, there has to be a primary stress, realized with a $\mathrm{H}^{*} \mathrm{~L}$ on the negative marker nem.

${ }^{8}$ Note that I make a distinction, following Haegeman (1995), between the licensing of an n-word by a negative marker and the phenomenon of Negative Concord, which is the co-occurrence of several n-words.
} 
preverbal n-words in $(20 \mathrm{~b}, \mathrm{c})$ are universally quantified and scope over sentential negation. In this paper, I adopt Surányi's analysis of Hungarian n-words. Furthermore, I assume, following Puskás (1999, 2002) and Surányi (2003), that n-words are not intrinsically negative. The fact that the negative marker nem is obligatory is taken as evidence for the fact that $\mathrm{n}$-words are negative-dependent elements.

As illustrated in (17) and (18), DN in Hungarian differs minimally from NC in terms of the stress pattern associated with it. I now turn to the case of strong DN. Weak DN is the subject of the following section, Sect. 3.3.

\subsection{Strong DN in Hungarian}

As discussed in Sect. 2, the strong version of DN typically has a corrective function at the propositional level. This type of DN also occurs in Hungarian, with the following pattern:

(21) SEMELYIK FILMET nem ismerte senki.

no film-ACC NEG knew-3s n-person-NOM

'Nobody knew no film.'

The two n-words involved in the DN in (21) come with different intonation patterns. While the post-verbal senki 'nobody' is uttered with a flat deaccented prosody, the preverbal n-word, semelyik filmet 'no film-acc' bears a heavy primary stress, of the type $\mathrm{H}^{*} \mathrm{~L}$, signaled in the example by small capitals. This stress is usually associated with Focus in the preverbal position. Before concluding, as I intend to do, that the n-word occurs in the syntactic Focus position itself, we will briefly examine the properties of Focus in Hungarian. ${ }^{9}$ I will claim that strong DN arises when one of the n-words occurs in the Focus position. I will also claim that the corrective import of this type of DN obtains as a result of the presence of a VERUM operator, which licenses the n-word in the Focus position and yields the polar interpretation.

\subsubsection{Focus}

In order to clarify the corrective nature of sentence (21) above, we must briefly discuss the function of preverbal Focus. As is well known, Hungarian is a structural Focus language (see Szabolcsi 1981; Horváth 1986; É. Kiss 1987 and subsequent literature). The canonical Focus position in Hungarian is the position to the immediate left of the inflected verb (see Brody 1990; É. Kiss 1987, 2002 among others). When the Focus position is occupied, the verb particle obligatorily appears after the verb. This Focus position has been described as hosting constituents with an "identification by exclusion" value (see Kenesei 1986, 2006), also referred to as "exhaustive focus", following Szabolcsi (1981). ${ }^{10}$ Identification by exclusion is also associated with a

\footnotetext{
${ }^{9}$ The Focus properties of negative quantifiers are not so clear, though. As discussed in Surányi (2006), a preverbal n-word is not necessarily in the (standard) Focus position: there are cases of non-focus occurrences of pre-verbal n-words. However, in the examples discussed here, the stress pattern in which it participates makes it highly plausible that the n-word is actually focused.

${ }^{10}$ On different kinds of Foci, see e.g. É. Kiss (1998).
} 
corrective function. Example (22a) below illustrates a sentence with neutral word order, where the particle precedes the verb and the object follows it. In (22b), the object occurs in the preverbal Focus position. It may either be interpreted as exhaustive (entailing that the relation denoted by the association with the rest of the sentence holds of no other entity) as illustrated by (22c), or as contrastive/corrective, functioning thus as a correction to a previous statement involving the rest of the sentence (22d).
a. Felhívtam Évát tegnap.
PART-called-1s Eva-ACC yesterday.
'I called up Eva yesterday.'
b. ÉvÁT hívtam fel tegnap.
Eva-ACC called-1S PART yesterday
'I called up EvA yesterday.'
c. ÉVÁt hívtam fel tegnap, és csak ôt.
Eva-ACC called-1S PART yesterday, and only her-ACC
'I called up EvA yesterday, and only her.'
d. ÉvÁt hívtam fel tegnap, nem Csabát.
Eva-ACC called-1S PART yesterday, not Csaba-ACC
'I called up EvA yesterday, not Csaba.'

A standard view about the contribution of Focus is that it triggers the structuring of the proposition denoted by a sentence. ${ }^{11}$ By structuring, I mean the partitioning into a focused constituent and the focal presupposition. The focused constituent triggers a set of alternatives, which consists of a set of propositions that contrast with the focal presupposition, and which are "obtainable from the ordinary semantic value by making a substitution in the position corresponding to the focused phrase" (Rooth 1992: 76). The set of alternatives is salient, but not necessarily explicitly mentioned. Moreover, it contains only alternatives that are type-identical with the focused expression.

The interpretation of contrastive/exclusive Focus is that, given a set of alternatives, only the one given in the Focus constituent contributes to a value of True, and all the other alternatives are excluded. The focused expression thus contrasts with a previously uttered member of the set of alternatives (for a discussion of alternative semantics and contrastive Focus, see e.g. Rooth 1985, 1992). ${ }^{12}$

However, it has also been observed that Focus can have another function. Höhle (1992) observes that in some situations, a stress on the verb has the effect of conveying that the speaker takes it for true that $p$ :

\footnotetext{
${ }^{11}$ I will not discuss here either the details or the consequences of the different proposals. The reader is referred to the rich relevant literature, among which—but not exhaustively, von Stechow (1991), Rooth (1985, 1992), Krifka (1991), Kratzer (1991).

${ }^{12}$ For Rooth, the relevant type of Focus is the one associated with only. Significantly, the kind of focus interpretation in the preverbal Focus position in Hungarian, i.e. the identification by exclusion, is somewhat similar to the only type of Focus (note that constituents marked with the overt csak 'only' in Hungarian occur in the preverbal Focus position). I will therefore assume that the analysis can extend to the Hungarian contrastive Focus cases. See also É. Kiss (1998). Many thanks to Donka Farkas for discussing this point with me.
} 
Speaker A: Ich habe Hanna gefragt, was Karl grade macht, und sie hat die alberne Behauptung aufgestellt, dass er ein Drehbuch schreibt. 'I asked Hanna, what Karl is doing, and she made the silly supposition that he is writing a scenario.'

Speaker B: (Das stimmt) Karl schreibt ein Drehbuch.

'(That's true), Karl is writing a scenario.'

(Höhle 1992, glosses are mine)

Here, Speaker B considers it true that Karl is writing a scenario. Höhle claims that (24) below has the same effect:

Speaker B: Es trifft zu/is wahr, dass Karl ein Drehbuch schreibt.

'It is accurate/true that Karl is writing a scenario.'

(Höhle 1992, glosses are mine)

Höhle proposes that the effect of the stress on the verb as conveying the speaker's commitment to the truth of $p$ can be derived from introducing a predicate "true". He calls this stressed meaning component VERUM. The cases discussed above are therefore cases of Verum Focus.

Höhle notes that as, in the approach proposed (i.e., $p \Leftrightarrow \operatorname{TRUE}(p))$, such an abstract VERUM element might seem ad hoc. However, he argues that VERUM is not a real truth predicate but rather an Illocution type Operator: "This idea takes plausibly into account the intuition about the effect of the Verum Focus and has the advantage that similar meaning elements are justified through totally independent considerations" (Höhle 1992:118; translation mine).

We have seen above that Focus triggers a set of alternatives. It is not clear, however, whether Verum Focus has the same effect of implying some relation with (paradigmatic) alternatives. Höhle proposes that VERUM forms, along with negation and expressions like maybe, probably, etc., a class WF of elements that the speaker needs to express his opinion about the truth of $p$. Because they can recursively embed, however, they cannot really be considered as alternatives. ${ }^{13}$ The representation of mutually exclusive alternatives refers narrowly to "normal" cases (i.e. cases of standard semantic focus). But in the case of Verum Focus, "one should not interpret/consider the set of possible alternatives, that is, the amount [of elements] there is in (the class) WF itself, but the number of possible combinations of the elements of (the class) WF" (Höhle 1992:128; translation mine).

However, as also noted in Karagjosova (2006), focused negation as Verum Focus does not seem to invoke all the alternatives listed above. Only the positive counterpart to the expression appears as an appropriate alternative. Karagjosova proposes that the relevant alternatives are not as given by Höhle, but only comprise the positive and the negative value of $p\{p, \neg p\}$.

Romero \& Han (2002) give an interesting and convincing formalization of Höhle's Verum. Their analysis relies on the intuition that VERUM (or alternatively, the epistemic adverb really) is used not to assert that the speaker is entirely certain about the truth of $p$, but rather to assert that the speaker is certain that $p$ should be added to

\footnotetext{
${ }^{13}$ Real, semantic alternatives are mutually exclusive and hence cannot embed recursively.
} 
the Common Ground (CG). For these authors, VERUM (or really) is an epistemic operator. $^{14}$

While their analysis focuses on yes/no questions, they observe that a similar VERUM operator has been claimed to arise in declaratives in certain cases of focal stress on polarity elements. Focal stress on aux, $\mathrm{V}$ or neg has a contrastive use. Furthermore, sometimes the polarity focus in declaratives is interpreted as VERUM Focus, where the function of stress is to emphasize or insist on the truth or falsity of $p$. Building on the function of Verum Focus as epistemic operator and on the role of negation itself, Romero \& Han define a negative version of VERUM as contribution of VERUM on not:

$$
\begin{aligned}
& {\left[\left[\mathrm{NOT}_{i}\right]\right] }=\lambda p\langle s, t\rangle \lambda w \cdot \forall w^{\prime} \in \operatorname{Epi}_{x}(w)\left[\forall w^{\prime \prime} \in \operatorname{Conv}_{x}\left(w^{\prime}\right)\left[\neg p \in \mathrm{CG}^{\prime \prime}\right]\right] \\
&=\text { FOR-SURE-CG-NOT } \\
& x
\end{aligned}
$$

$\operatorname{Epi}_{x}(w)$ is the set of worlds that conform to $x$ 's knowledge in $w \cdot \operatorname{Conv}_{x}\left(w^{\prime}\right)$ represents the set of worlds where all the conversational goals of $x$ in $w^{\prime}$ (e.g. attain maximal information while preserving truth) are fulfilled. Lastly, $\mathrm{CG}_{w^{\prime \prime}}$ is the Common Ground or set of propositions that the speaker assumes to be true in $w^{\prime \prime}$.

Thus, the contribution of Verum Focus on NOT is used not to assert that the speaker is certain that $p$ is false, but rather to assert that the speaker is certain that $p$ should not be added to the Common Ground. Below is an example from Romero and Han:
a. They will NOT finish on time
b. LF: [FOR-SURE-CG-NOT [IP they will finish on time]]
c. $[[\mathrm{CP}]]=\lambda w . \forall w^{\prime} \in \operatorname{Epi}_{x}(w)\left[\forall w^{\prime \prime} \in \operatorname{Conv}_{x}\left(w^{\prime}\right)\right.$
$\left[\lambda w^{\prime \prime \prime} . \neg\right.$ fin $\left(\right.$ they, $\left.\left.\left.w^{\prime \prime \prime}\right) \in \mathrm{CG} w^{\prime \prime}\right]\right]$
$=$ 'It is for sure that we should add to CG that it is not the case that they will finish on time.'

\subsubsection{DN as Verum Focus}

Let us come back to example (21) repeated here:

$$
\begin{aligned}
& \text { SEMELYIK FILMET nem ismerte senki. } \\
& \text { no film-ACC NEG knew-3S n-person-NOM } \\
& \text { 'Nobody knew no film.' }
\end{aligned}
$$

The n-expression semelyik filmet 'no film' occurs in a preverbal position, and carries a strong emphatic stress. It is interpreted as providing a correction. It therefore occupies the Focus position. However, the contrast does not introduce a set of alternatives to

\footnotetext{
${ }^{14}$ Romero \& Han (2002) specify that the denotation of this epistemic operator corresponds to FOR-SURE $x$, "where $x$ is a free variable whose value is (usually) contextually defined" (Romero \& Han 2002:9).
} 
the n-word. Rather, the sentence is interpreted as a correction to some proposition $p$, where $p$ is negative. A possible expression of $p$ could be: ${ }^{15}$

(27) Egy/néhány filmet nem ismert senki.

A/a few film-ACC NEG knew-3s n-person-NOM

'There was a film/several films that nobody knew.'

I claim that the n-expression semelyik filmet 'no film' occurring in the Focus position in (21) carries out the emphatic contrastive function discussed above. It is interpreted as associated with an epistemic operator that insists on the falsity of $p$, the operator identified as Verum Focus.

How can we give an analysis of (21) as an expression of Verum Focus? Indeed both Höhle's and Romero \& Han's analyses concern expressions of sentential negation, as rendered by the sentential negative marker nicht/not. I would like to propose that a similar analysis can extend to cases of DN with two n-words. The very fact that the n-word occurs in the Focus position argues in favor of such an approach.

Recall that standard Focus has the effect of triggering alternatives given by the NP in the Focus position. However, in the case of negative elements, such recourse to alternatives cannot hold. N-words do not trigger alternatives of the same kind. (21) cannot mean that it is no film, as opposed to a film, several films, two films, ...\} that was not known by anybody. Rather, it appears as a (polar) negation of the whole proposition below:
a. Some film was not known by anybody.
b. There is a film such that no individual knows the film.
c. $\exists x[$ Film $x \wedge \neg \exists y($ Person $y \wedge \operatorname{Know} y x)]$

Using Romero \& Han's approach, we can give an LF and a paraphrase of (21) where the Verum operator contributes it is for sure not. This operator, having the polar value Neg, will license the n-word:

a. $\mathrm{LF}=$ [FOR-SURE-CG-NOT [IP there is a film such that no individual knows it]]

b. 'It is for sure that we should add to CG that it is not the case that there is a film such that no individual knows it.'

\footnotetext{
${ }^{15}$ Note that, as discussed in Horn (1989), such wide-scope negation may come as a correction not only to overt utterances, but also to implicatures and presuppositions associated with utterances. Thus, (19) may also be felicitous as an answer to the following question:

(i) Melyik filmet nem ismerte senki? Which film-ACC NEG knew-3s n-person-NOM

'Which film did nobody know?'

Such a question triggers the presupposition that some film was not known by anybody. And, crucially, the wh-expression melyik filmet 'which film' is specific, in that it presupposes (at least) a set of films, or even the availability of a given film the speaker has in mind. The DN sentence will then come not as a correction to the actual utterance, but as a cancellation of the presupposition.
} 
In order to understand the full analysis, we need to say a few words about the status of n-words. The post-verbal n-word appears as an existentially quantified element. Surányi (2006) discusses at length the fact that Hungarian n-words are ambiguous between a universal and an indefinite reading. The author shows convincingly that in a post-verbal position, n-words may be indefinites. I will take the indefinite here to be existentially closed under negation. This seems to be confirmed by whatsoever/at all modification (see Lee and Horn 1994):

(30) SEMELYIK FILMET nem ismert egyáltalán senki.

No film-ACC NEG knew-3s at all n-person-NOM

'No film is such that nobody at all liked it.'

The n-word in the Focus position, on the other hand, has a rather weird status. As is well known from the literature on Hungarian (see Szabolcsi 1981; É. Kiss 1987 and subsequent literature) universal quantifiers cannot occur in the (structural) Focus position. What is just as problematic is that existentials are banned as well (É. Kiss 1987). Recall that the presence of an element in the Focus position triggers verbparticle inversion. The examples in (31) below show that when universal quantifiers and existential quantifiers occur in the preverbal domain, they do not trigger verbparticle inversion. Therefore, they do not occupy the Focus position (examples from É. Kiss 1987, boldface mine):

a. János mindig meg ijed.

John always PERF gets-frightened

'John always gets frightened.'

b. *János mindig ijed meg.

c. Valamit el veszített Péter. something-ACC away lost Péter

'Peter lost something.'

d. *Valamit veszített el Péter.

This has led Surányi to propose that the n-word in the Focus position is an indefinite, which needs to be bound by some operator, and depends on a distinct licensor. ${ }^{16}$ I borrow this analysis, and underline that it finds here further confirmation in the observation that the relevant alternative to the focused sentence contains an indefinite. However, the nature of the operator, I claim, is crucial. Following Höhle and Romero \& Han, I have assumed that VERUM is an epistemic operator. I have also adopted Romero \& Han's proposal that negation with VERUM involves an epistemic negative

\footnotetext{
${ }^{16} \mathrm{~A}$ reviewer asks whether Hungarian n-words are truly ambiguous or if the two sets of n-words are distinguished by prosody, as in the Greek data discussed in Giannakidou (1998, 2000). To the extent that $n$-words which occur in the Focus position — and which cannot have the universal reading-do bear some heavy stress, it might be plausible to distinguish them from their universal counterparts in terms of intonation. On the other hand, Greek emphatics have been argued to be universally quantified. If Hungarian ends up having a systematic prosodic pattern associated with one or another of the quantificational imports, as still needs to be examined in detail, it would, at fist sight, turn out to have the reverse pattern. However, the prosodic facts of Hungarian are much more subtle, because of the strong relationship quantified-and non-quantified —elements bear to information structure and associated syntactic structures.
} 
operator (see (29) above). I propose that the licensor is the VERUM operator, and the $\mathrm{n}$-expression semmelyik filmet in the Focus position is indeed an indefinite, licensed by $\mathrm{VF}^{\mathrm{NOT}}$ and bound by existential closure under negation, yielding (21) above. ${ }^{17}$ Because the two n-words are licensed by different negative operators, the DN reading obtains.

\subsubsection{The syntax of strong $D N$}

That strong DN arises in the presence of Focus has clear syntactic consequences. Indeed, Focus in Hungarian is recognized as a phenomenon that is associated with specific syntactic behaviors. As discussed above in Sect. 3.2.1, identificational or corrective Focus is associated with the strictly adjacent preverbal position, a position that is reached via syntactic movement. I claim that DN obtains if an n-word is licensed not only semantically, but also syntactically in this Focus position.

Let us first discuss the syntactic licensing of sentential negation. I assume, following much work in the field (see Belletti 1990; Haegeman 1995 for cross-linguistic perspectives, and Puskás 1994; Tóth 1995 a.o. for Hungarian) that nem realizes the head $\mathrm{Neg}^{0}$, and hence bears an interpretable feature $i \mathrm{Neg}$. An n-word, being non-negative per se (see discussion and references above), bears an uninterpretable feature $u$ Neg. ${ }^{18}$ Several recent studies have examined the relation between interpretable/uninterpretable features and Agree. Pesetsky \& Torrego (2007) claim that feature valuation and feature interpretability must be dissociated, and Agree is a matter of unvalued probes c-commanding valued or unvalued goals. Bošković (2007) argues that an uninterpretable feature on a goal triggers movement. In other words, Move is triggered in a configuration where an interpretable feature on a probe c-commands an uninterpretable feature on a goal. In his system, Agree is the mirror image, namely, it corresponds to a configuration where an uninterpretable probe c-commands an interpretable goal. Pesetsky \& Torrego's approach may find a direct application in the case of Hungarian DN. However, the system appears to be redundant with respect to negation, and therefore provides an unnecessarily complex tool. ${ }^{19}$ As for Bošković's proposal, it raises problems for NC in a language like Hungarian, in which Move is typically triggered where interpretable features are c-commanded by an interpretable feature. I will adopt the proposal given in Zeijlstra (2010), who argues, reversing Bošković's proposal, that Move arises when an element carrying an uninterpretable feature "finds a feature $[\mathrm{iF}]$ in its search domain and attracts it to

\footnotetext{
${ }^{17}$ As suggested to me by Maribel Romero (p.c.), this operator could be similar to/the same as the one which triggers negative inversion in English for example.

${ }^{18}$ The status of Hungarian n-words has been abundantly discussed in the literature in recent years. Whereas Puskás (1998, 2000), Olsvay (2000, 2006), É. Kiss (2002) adopt the view that $n$-words have a [+neg] feature, Puskás $(1999,2002)$ and Surányi $(2002,2003)$ claim that they are non-negative but negativedependent elements.

${ }^{19}$ The four-way system, which distinguishes between valued and unvalued features on the one hand and interpretable and uninterpretable features on the other hand, appears to provide a finer-grained distinction between elements. But in the case of Hungarian negation, uninterpretable features are always paired with valued features, which thus need an interpretable feature associated with an unvalued feature to agree with. Since no other combination seems to be at play, the system — in this case — turns out to be redundant.
} 
its spec position to have its [uF] feature checked" (Zeijlstra 2010:129). Agree is a case of interpretable probe c-commanding an uninterpretable goal. In such a context, Zeijlstra defines Agree as follows:

(32) Agree in a relation between a probe $\alpha$ and a goal $\beta$, such that

(i) $\alpha$ and $\beta$ are in a proper local domain

(ii) $\alpha$ has some uninterpretable feature $[\mathrm{uF}]$

(iii) $\beta$ has a matching interpretable feature $[\mathrm{iF}]$

(iv) $\alpha$ is c-commanded by $\beta$

(v) there is no matching goal carrying [iF] in between $\alpha$ and $\beta$

(Zeijlstra 2010:130)

Consider now a case of sentential negation with an n-word:

Nem látott Éva “senkit.
NEG saw-3s Eva-NOM n-person-ACC
'Eva didn't see anybody.'

The Neg head, realized as nem in Hungarian, has an interpretable feature $i \mathrm{Neg}$. The $\mathrm{n}$-word senkit, carrying $u \mathrm{Neg}$, acts as a probe. It enters into Agree with the Neg head and its feature is checked. ${ }^{20}$

Under this version of Agree, feature checking as deletion applies to bare features and does not require pied-piping of phonological material. Any further operation will be motivated by some other need. Therefore, when an n-word occurs in the sentence, it will necessarily enter into an Agree relation with the negative head and the (default) reading will be that of a single negation. I also assume that multiple instances of n-words will need to check their uninterpretable feature with the Neg head, entering thus into an NC relation.

Given this analysis, we expect DN to be impossible. I propose that this is precisely why DN readings obtain only under the conditions described above, namely, if one n-word occupies a particular syntactic operator-related position. Recall that strong $\mathrm{DN}$ is constrained by the presence of an n-word in the Focus position. The question is then how this n-word is licensed.

It was mentioned above that Hungarian preverbal Focus is an exhaustive type of Focus. I assume, following Brody (1990), that it is encoded as a Focus head which carries a Focus feature of the kind [+exhaustive], very much in the line of the leftperipheral Focus head discussed in Rizzi (1997).

I propose that the structural Focus head, $\mathrm{Foc}^{0}$, may also be associated with the VERUM operator, which is phonologically null. The head $\mathrm{Foc}^{0}$ comes with an uninterpretable V(ERUM)-Focus feature. Recall that Verum Focus comes in two flavors, the one we are interested in having a polarity [neg]. The null head will thus also carry an uninterpretable feature $u$ Neg. It will look for a matching feature in its search domain. The n-word (which ultimately appears in the Focus position) bears an interpretable feature $i \mathrm{~V}-\mathrm{FOC}$, because it is specified as "Focus" and consequently phonologically marked for it. The null head attracts the n-word to its specifier to have its

\footnotetext{
${ }^{20}$ See Puskás (2002) for a similar, although more embryonic, proposal. See also Surányi (2003) and Watanabe (2004) for other analyses of NC in terms of a feature checking mechanism.
} 
feature checked. The n-word, like all n-words, carries an uninterpretable Neg-feature. The latter will check, in a local Agree relation, the interpretable Neg feature of the head.

The n-word bearing V-Foc does not enter into any relation with the sentential $\mathrm{Neg}$ head (the latter will be independently checked by the (non-focused) n-word with which it enters into an Agree relation, as described above (33)). ${ }^{21}$ Because the focused n-word escapes the standard Agree relation, it cannot participate in NC, and only the DN reading is available.

The (simplified) structure of a strong DN sentence is thus the following:
a. SEMMELYIK FILMET nem látta senki. No film-ACC NEG saw-3s n-person-NOM
b. [FocP SEMMELYIK FILMET [Foc V-Foc [NegP nem látta $\ldots$... [vP senki látta $_{i}$ [vptátta semmelyik fllmet ]]]]]

The surface position of $n e m+\mathrm{V}$ has been a controversial issue in the literature on Hungarian negation. Various analyses have proposed that the complex unit occurs in $\mathrm{Neg}^{0}$, while others claim that it raises to $\mathrm{Foc}^{0} .^{22}$

Raising the verb to $\mathrm{Foc}^{0}$ (to account for adjacency) requires postulating an extra $[+f o c]$ feature on the verbal/negative head, which is semantically not motivated. Rather, the proposal that Hungarian has a covert Focus marker that fills the Foc $^{0}$ head is more in the spirit of what is observed for other structural Focus languages.

Another issue which would require further discussion is the absence of observed Relativized Minimality effects, despite the fact that the chain of the focused n-word crosses NegP and the n-word chain. One possible explanation, which can only be sketched out here, resides in the feature composition of the respective elements. As was discussed above (Sect. 3.2.2) post-verbal n-words are indefinites. The focused n-word, despite its existential nature, is different, in the sense that a Focus triggers (some) alternatives, therefore entails some presuppositional import. It has been shown in Baunaz (2008) that existential quantifiers come in three flavors, namely: bare (nonpresuppositional) indefinites, presuppositional elements requiring a range of values,

\footnotetext{
${ }^{21}$ The fact that the two kinds of n-words (the V-Foc n-word and the regular neg-word) do not participate in the same neg-chain could be explained by Criterial Freezing (Rizzi 2004): Once a feature is checked, the chain cannot further extend, and therefore cannot participate in another chain. Thanks to Ur Shlonsky (p.c.) for suggesting this.

${ }^{22}$ One argument in favor of the V-to-Neg-to-F movement was motivated (see e.g. Puskás 1994) by the observation that negation triggers particle-verb inversion, a phenomenon also found in focusing:
}

(i) a. Éva elment.

E.NOM PART-left

'Eva left.'

b. ÉVA ment el.

E.NOM left PART

'It is EVA who left.'

c. Éva nem ment el.

E.NOM NEG left PART

'Eva didn't leave.'

There are different proposals as to why this inversion occurs (see e.g. É. Kiss 2002). 
and specific presuppositional elements with a specific value. The data discussed in Baunaz clearly show that intervention effects are dependent on these distinctions and that a range type of quantifier is blind to bare indefinites. The same analysis should be transposable to Hungarian n-words, and is under current investigation. Therefore, a focused n-word is expected to be blind to the presence of an indefinite n-word.

\subsection{Weak DN in Hungarian}

Let us now turn to the other type of DN. The discussion in Sect. 2 has revealed that some instances of DN can trigger a weaker set of alternatives, with the implicature that at least the one expressed by the DN sentence is not true. Example (35) illustrates this type of DN:

$$
\begin{aligned}
& \sqrt{ } \text { Semmiröl "senkivel nem beszélt. } \\
& \text { n-thing-DELAT } \\
& \text { n-person-INSTR NEG spoke-3S } \\
& \text { 'About nothing, he spoke with nobody.' }
\end{aligned}
$$

I have labeled this type weak DN because, as opposed to the cases discussed in Sect. 3.2, the presence of negation triggers a larger set of weak alternatives. However, the alternatives do not arise where we expect them. The DN sentence cannot be a mere denial of some previous utterance. Rather, it conveys the meaning that (at least) as far as the negative constituent with the relevant intonation is concerned, and in the context of the sentence, $p$ is not true. In (35) above, this amounts to the claim that "from the set of things that could have been talked about in this context, (at least) about nothing, it is not the case that he spoke with nobody". The implicature is that there is at least something about which he spoke with somebody.

Of crucial interest for us here is that this subtle difference in meaning is due to the distribution of the two n-words and their respective intonation. The n-word senkivel 'with nobody', which occurs to the immediate left of the negative marker, bears a primary stress, of the type $\mathrm{H}^{*} \mathrm{~L}$. However, I will show that it does not occupy the structural Focus position. On the other hand, I claim that this n-word is involved in the main sentential negation, and I will refer to the relation it bears with the sentential negative marker as the "primary negative chain". As for the other n-word, semmiröl 'about nothing', it occupies a position which linearly precedes that of the stress-bearing n-word. Moreover, it obligatorily bears the $\mathrm{L} * \mathrm{H}$ intonation discussed in Sect. 2. In Hungarian, this position hosts Contrastive Topics. In order to make my claims clearer, I will ask the reader to follow me through a brief discussion of Contrastive Topics (henceforth CT).

\subsubsection{Contrastive Topics (CT)}

In a detailed study of the semantics of CT in Hungarian, Gyuris (2002) lists the characteristics of the construction. She observes that CTs surface in the left periphery and receive a rising intonation. They bear an eradicating stress and introduce a contrast between the denotation of the CT and other elements of the same type. ${ }^{23}$

\footnotetext{
${ }^{23}$ Formally, CT comes with a specific intonation, characterized as a "fall-rise" or $\mathrm{L} * \mathrm{H}$ (see also Lambrecht 1994; Molnár 1998). Gyuris refers to Kálmán and Nádasdy's (1994) definition, which states that an erad-
} 
Gyuris claims that this set of properties is characteristic of prototypical CTs, but that a constituent interpreted as CT may lack one or more of them. The author proposes various tests to identify $\mathrm{CT}$ in Hungarian. In addition to the typical $\mathrm{L} * \mathrm{H}$ intonation usually associated with CT, it is generally possible to insert a co-referential pronoun or certain particles (such as az 'that', ott 'there', bezzeg 'as opposed to others', azért, pedig, bizony, aztán, ugyan 'however') after the CT (examples from Gyuris 2002): ${ }^{24}$

a. [Cт Máriát] azt 'meglátogattam.

Mary-ACC that-ACC PREF-visited

'Mary, I HAVE visited.'

b. [CT Legalább két könyvet] azért 'minden diák elolvasott. at least two book-ACC however every student-ACC PREF-read

'Every student has read at least two books, however.'

Gyuris argues that although CTs appear in the preverbal field, and are in this respect similar to Topics, they cannot be assimilated to the latter. Indeed, when a constituent occupies the Topic position, the sentence expresses a proposition that predicates a property of an individual (see also Maleczki 2003). In these cases, the referent of the logical subject, that is, of the constituent in the Topic position, has to be identified independently of the statement. But CT does not satisfy the requirement that its referent be independently identifiable. Gyuris argues that CTs are referentially dependent on other expressions in the sentence:

$$
\begin{aligned}
& \text { [CT Minden könyvet] [F 'két diák] olvasott el. } \\
& \text { Every book-ACC two student read PREF } \\
& \text { 'Two students are such that they read all books.' } \\
& \text { \# 'Every book is such that it was read by two students.' }
\end{aligned}
$$

In example (37) above, minden könyvet 'every book' does not refer to the totality of books available in the context, but it may refer to the totality of books assigned to a student in a context where different sets of books are given to each student. So the interpretation may be that (only) two students read all the books they were given. $^{25}$

icating stress is a main stress that cannot be followed by another main stress, unless the latter is also an eradicating stress.

${ }^{24}$ Gyuris' pref corresponds to the verbal particle glossed part in my examples. She also uses ' (single quote) to signal emphatic Focus-like stress on the verb or the quantifier (see also footnote 26 below).

${ }^{25}$ Gyuris proposes that the explicit reference to context be built into the denotation of the CT, in the following way:

(i) [CT 'Semelyik film] [F 'Jánosnak] nem tetszett. none movie John-DAT not liked

'It was John who didn't like ANY of the movies.'

(ii) $\lambda v \exists z\left[\operatorname{movie}(z) \wedge C^{\prime}(z) \wedge z=v\right]$

(Where the predicate $C^{\prime}$ picks out contextually relevant individuals.) 
Recently, the semantics of CT has drawn researchers' attention (see a.o. Lee 1999, 2003, 2006; Tomioka 2009; Yabushita 2008). One approach, which builds on the notion of alternatives, is developed in Büring (1999). The core proposal is that CT marking, namely the presence of a $\mathrm{L}^{*} \mathrm{H}$ (a B-accent, following Bolinger 1965; Jackendoff 1972), serves to indicate the presence of a strategy. By strategy, Büring means that the discourse comes with a question, which is not answered directly, that is, in one step. Rather, it may be divided into sub-questions, which appear as alternative questions. The CT constituent then functions as an answer to one of the sub-questions, but the alternatives are somehow accessible, that is, they are not mutually exclusive. In the example below from Büring (1999), the index CT indicates a contrastive topic with an $\mathrm{L}^{*} \mathrm{H}$ intonation and $\mathrm{F}$ indicates a focus with a $\mathrm{H}^{*} \mathrm{~L}$ contour:

FRED $_{\mathrm{CT}}$ ate the $\mathrm{BEANS}_{\mathrm{F}}$

A somewhat simplified version of the derivation of the set of questions will be:

a. What did Fred eat? (Replace the focus by a wh-word.) ${ }^{26}$

b. What did Fred eat?

c. What did Mary eat?

Form a set of questions by replacing the con-

d. What did ... eat?

trastive topic with some alternative to it.

Büring claims that a CT signals "that the sequence is part of a larger discourse which-since it is not given in the actual example-the competent speaker can only guess at, using the information provided by the location of CT and focus in the sentence" (Büring 1999:10).

One of the complications that arises with the notion of Contrastive Topic is that the terminology may lead to confusion. Indeed, whereas most authors have retained the standard label, it must be emphasized that CT is by no means a Topic in the standard conception, i.e. an element that is associated with notions such as givenness or referentiality. Rather, as might be clear from Gyuris's and Büring's work, and is also emphasized in other approaches (Lee 2003; Molnár 1998), CT involves a quantificational element. Therefore, its contribution is by no means that of a Topic. Rather, is should be interpreted as an element which, very much like Focus, triggers a set of alternatives. However, the contribution of Focus to the sentence resides in the fact that inserting the focused element yields the value true with respect to the sentence, while all other alternative elements yield the value false. A CT marking, on the other hand, contributes a value true for the element, but does not exclude the possibility that other alternatives of the set also yield a value true. Hence the proposal (see a.o. Molnár 1998) that CT introduces weak alternatives. In that sense, CT involves quantification since it comes with a set of alternatives. ${ }^{27}$

\footnotetext{
${ }^{26}$ Although Büring claims that CT builds on Focus, it is not clear what the actual function of this Focus is. The sub-questions introduced by CT build on the wh-question associated with Focus, but the latter may well not be of the exhaustive kind. Jacobs (1996) considers the I(ntonational)-Contour, rather than the actual semantics of the emphasized element that the CT builds on. See also Molnár (1998) for a discussion of the various I-Contours.

${ }^{27}$ Wagner (2008) proposes an analysis of Contrastive Topics as involving two nested covert Foci, similarly to the nested overt scope markers like even and only, as in 'Even John drank only water', where the CT
} 


\subsubsection{DN in a CT context}

Having introduced the notion of CT, we may now come back to example (35), repeated here:

$$
\begin{aligned}
& \sqrt{ } \text { Semmiröl "senkivel nem beszélt. } \\
& \text { n-thing-DELAT } \\
& \text { n-person-INSTR NEG spoke-3S } \\
& \text { 'About nothing, he spoke with nobody.' }
\end{aligned}
$$

In (35) above, one of the n-words, senkivel 'with nobody', occurs to the immediate left of the negative marker. It participates in the primary neg-chain, to which I come back below. The other n-word, semmiröl 'about nothing', bears the fall-rise intonation typical of CT. In addition, an adverbial may be inserted after it:

$$
\begin{array}{ccc}
\sqrt{ } \text { Semmiről azonban "senkivel nem beszélt. } \\
\text { n-thing-DELAT however } & \text { n-person-INSTR NEG spoke-3s }
\end{array}
$$

'About nothing, however, he talked to nobody.'

Recall also that Gyuris claims that CT constituents may exhibit referential dependency. This is most straightforwardly illustrated in the example below: ${ }^{28}$

$$
\begin{aligned}
& \sqrt{ } \text { Semmit "senkitôl nem vettem el. } \\
& \text { n-thing-ACC } \\
& \text { 'I took nothing from nobody.' }
\end{aligned}
$$

The referential dependency illustrated here concerns the interpretation of semmit 'nothing' since the set of things that the speaker took from the persons in the context may co-vary with the persons. ${ }^{29}$ Therefore, I conclude that the n-word bearing the

corresponds to the outer Focus, and builds on the interpretation of an inner Focus. Note also that Kenesei (1986) labeled this type of constituent kontrafókusz rather than contrastive topic, referring explicitly to its focal nature.

${ }^{28}$ Thanks to a reviewer for providing this example and pointing out its relevance to the discussion.

${ }^{29}$ In fact, as is also mentioned briefly in Gyuris (2002), the "specific" nature of the CT also plays a role in its acceptability. In my examples, semelyik film 'no film' is in some sense more "specific" than senki 'nobody'. Although I am not sure we use the term "specific" in the same way, I also consider CT constituents, including quantificational ones, to be more "context-bound" than pure quantifiers. I also think that this referential dependency may explain interesting variations in the acceptability of weak DN structures. While some DN readings are rather straightforward, others simply do not go through. Compare (i) and (ii):

(i)

$$
\begin{aligned}
& \sqrt{ } \text { Semelyik filmet "senki nem szerette. } \\
& \text { No film-ACC n-person-NOM NEG liked-3s } \\
& \text { 'Nobody liked no film.' }
\end{aligned}
$$

$\begin{array}{ccc}\text { (ii) } & \# \text { Senki } \\ \text { n-person-NOM no } & \text { nomilyik filmet nem szerette. }\end{array}$

The lack of referential dependency makes examples such as (ii) much more difficult to compute than (i) above. Indeed, (i) is appropriate in a situation where people come to see films at a film festival. The set of films under scrutiny may be easily determined by the rest of the sentence, which implicates the existence of a contextually defined set of films that people liked. On the other hand, the set of individuals in (ii) is much more difficult to determine with respect to the rest of the sentence. 
fall-rise is indeed interpreted as a Contrastive Topic. (For a detailed discussion of the motivations, see also Puskás 2006.)

We must now turn to the contribution of each of the n-words to the DN interpretation. For ease of discussion, I will label the n-word which is associated with the CT interpretation, and which comes linearly first, CT n-word; the n-word, which is immediately left adjacent to the negative marker, will be labeled Pre-Neg n-word.

Although the Pre-Neg n-word appears to the immediate left of the negative marker, I assume that, as opposed to the cases of strong DN, it does not occupy the structural Focus position. Rather, it occurs in a higher left peripheral position that has been labeled DistP (Szabolcsi 1997) and identified as Field 1 in Surányi (2006). This is the position preverbal universal quantifiers target (42a) and in which a preverbal n-word can appear in simple negative sentences (42b).

a. Mindenkinek telefonált Éva.

Everybody-DAT telephoned-3s Eva-NOM

'Eva called everybody.'

b. "Senkinek nem telefonált Éva.

n-person-DAT NEG telephoned-3s Eva-NOM

'Eva didn't call anybody.'

An n-word in this left-peripheral position participates in negation at the sentential level (42b) exactly as it does in the post-verbal position (see (19b) above), and may enter into NC with other n-words. In (35) above, the Pre-Neg senkivel 'with nobody' participates in sentential negation along with the negative marker nem, very much like in (42b).

What is crucial is that the CT n-word semmiröl does not participate in sentential negation. As Hungarian is a NC language, two n-words can, and by default do, participate in sentential negation jointly, rather than contributing individual negative forces to the sentence. But (35) is interpreted as DN because the CT n-word escapes standard NC. In order to understand the situation fully, let us decompose it into two steps.

Let us start with what I will consider as the basic negative sentence, with its LF:

a. "Senkivel nem beszélt.

n-person-INSTR NEG spoke-3s

'He spoke with nobody.'

b. For all individuals, IT IS NOT THE CASE THAT he spoke with them

As discussed above, the n-word senkivel occurs in the position in which universally quantified expressions occur in Hungarian. It is also universally quantified and scopes over (sentential) negation. Following standard diagnostics, it can be modified by $m a-$ jdnem 'almost': 30

\footnotetext{
${ }^{30}$ That $\mathrm{n}$-words in the preverbal quantifier field are universally quantified is also defended in Surányi (2006). 
(44) Majdnem senkivel nem beszélt.

almost n-person-INSTR NEG spoke-3s

'He spoke with almost nobody.'

The CT n-word, which occurs in the left periphery, does not participate in the sentential negation. It is interpreted as adding another negation:

$\begin{array}{lll}\text { a. } & \sqrt{ } \text { Semmiröl } & \text { "senkivel nem beszélt. } \\ \text { n-thing-DELAT } & \text { n-person-INSTR NEG spoke-3S }\end{array}$

b. For all individuals, IT IS NOT THE CASE THAT he spoke with them about nothing.

This CT element has several properties. It is an indefinite, which must appear in the scope of negation. And, despite its left-peripheral position, it has narrow scope. These two properties are illustrated below:

$$
\begin{aligned}
& \text { a. ?* } \sqrt{ } \text { Majdnem semmiröl "senkivel nem beszélt. } \\
& \text { almost n-thing-DELAT n-person-INSTR NEG spoke-3S } \\
& \text { b. } \sqrt{ } \mathrm{A} \mathrm{pro}_{i} / \text { saját }_{i} \text { bicikliét "senki }{ }_{i} \text { nem adja } \\
& \text { the pro/own bicycle-POSS-ACC n-person-NOM NEG give-3s } \\
& \text { kölcsön. } \\
& \text { loan } \\
& \text { ' } \sqrt{ } \text { His bicycle, nobody lends.' }
\end{aligned}
$$

(46a) shows that the CT n-word cannot be modified by almost, a property associated with existentially quantified expressions; (46b) illustrates the fact that the CT constituent scopes below the n-word senki.

In (45) above, sentential negation is introduced by the negative operator. The preNeg n-word is a universally quantified element that scopes over the negative operator. Hence, it participates in sentential negation. The CT n-word is a (Heimian) indefinite. As such, it must undergo existential closure. I assume, following Ladusaw (1992), that the indefinite must thus be roofed by negation, where roof corresponds to the operation that triggers the anchoring of the indefinite within the scope or restriction of an operator. However, as also noted by Ladusaw, the roof of an indefinite may, but does not have to, be its binder. When the n-words all participate in NC, the roof and the binder, namely the negative operator, are identical. But the CT n-word does not participate in NC. In order to solve this problem, we must separate the two issues. On the one hand, as a CT, the n-word must be bound by the relevant operator. I propose that it is a quantificational operator of the CT kind, very similar to a Focus operator (see Wagner 2008). ${ }^{31}$ This operator out-scopes negation, but, as proposed by Wagner, an operator and its associate can have different scopes. Therefore, the n-word can scope lower than other quantifiers in the sentence. On the other hand, the n-word being bound by a widescope operator, it is not free to undergo closure under negation directly. I propose

\footnotetext{
${ }^{31}$ Wagner (2008) analyzes CT as a Focus (see footnote 28) and considers the operator to be a Focus operator.
} 
that given that it must still be roofed by some negative element in order to contribute a negative meaning, it is parasitic on primary sentential negation. Hence the dependency effect observed above (see (41)). The fact that the two n-words can live next to each other escaping neg-absorption is therefore directly accounted for by the fact that the CT operator itself is outside the scope of sentential negation.

\subsubsection{The syntax of weak $D N$}

We must now examine the syntactic licensing of the n-words that contribute to sentential negation and to DN. Consider example (47) below:

$$
\begin{aligned}
& \sqrt{ } \text { Semelyik filmet "senki nem szerette. } \\
& \text { No film-ACC n-person-NOM NEG liked-3s } \\
& \text { 'Nobody liked no film.' }
\end{aligned}
$$

As was discussed in Sect. 3.3.2 above, the Pre-Neg n-word senki 'nobody' occurs in a left-peripheral position, which is distinct from the exhaustive Focus position. This position, labeled DistP in Szabolcsi (1997), is a target for stress-bearing quantificational elements in the left periphery. I have proposed that the Pre-Neg n-word is associated with the sentential negative marker nem to express sentential negation. Therefore, its licensing is very similar to that of the post-verbal n-word in our previous examples. Nem realizes the Neg head, and carries $i$ Neg. The $\mathrm{n}$-word bears a feature $u$ Neg. Nem probes its local domain and Agrees with the n-word, checking its $u$ Feature.

However, as opposed to the previous case, the n-word does not appear in-situ. It occurs in the preverbal domain, which, in Hungarian, corresponds to the left periphery. Since neg-licensing itself does not require overt movement, I take this to be evidence that overt neg-movement is triggered by another feature. In order to focus on the DN problem, I will not discuss the details of this movement and I will assume that the left-peripheral quantifier position encodes some (presentational) Focus feature which triggers overt movement of the n-word. ${ }^{32}$

Let us now turn to the CT n-word, realized as semelyik filmet 'no film' in (47). Recall that this n-word is an instance of negation occurring in the CT position, in-

\footnotetext{
left periphery:

(i) Evának telefonált mindenki. Eva-DAT telephoned-3s everybody-NOM 'Everybody called Eva.'

(ii) Evának nem telefonált senki. Eva-DAT NEG telephoned-3s n-person-NOM 'Nobody called Eva.'
}

${ }^{32}$ It was shown above that $\mathrm{n}$-words target the same left-peripheral position as (non-negative) universal quantifiers (see (42)). As a matter of fact, both n-words and universal quantifiers appear optionally in the

I assume that overt movement is motivated by some "focus" feature. However, the exact nature of this feature is irrelevant to the present discussion. The feature composition of such elements is under investigation in current research. 
terpreted as dependent negation. Following recent proposals (Molnár 1998; Gécseg 2002) I will assume that the position hosting Contrastive Topics (CTopP) is a left-peripheral projection located between TopP (which hosts "regular" topics) and DistP. Under this analysis, the presence of negative quantifiers in a pre-verbal position follows in a rather straightforward way, as an instance of internal merge to CTopP. I will assume that the head of CTopP contains the relevant operator discussed above. Movement to CTopP is thus triggered by some discourse related feature, such as a CT(-quantificational) feature. The head CTop ${ }^{0}$ carries an uninterpretable feature $u \mathrm{CT}$, and attracts to its specifier the element bearing a matching $i \mathrm{CT}$. I assume contrastive topics bear such a feature. ${ }^{33}$

On the other hand, the CT left-peripheral position itself does not automatically provide a DN reading. The weak DN reading arises only when the sentence contains another negative quantifier. In other words, the presence of the sentential negative marker nem is not sufficient. A sentence such as (48) below, which contains only one negative quantifier, is not interpreted as $\mathrm{DN}$, despite the fact that the negative quantifier bears a $\mathrm{L} * \mathrm{H}$ intonational contour:

$$
\begin{array}{ll}
\sqrt{ } \text { Senkit } & \text { "Éva nem látott. } \\
\text { n-person-ACC } & \text { Eva NEG saw-3s }
\end{array}
$$

'Eva didn't see (just) anybody.'

The DN contributing n-word is dependent on the presence-and licensing-of the regular, sentential negative chain. In that sense, it is parasitic on the primary negrelation.

Parasitic licensing is a (well)-known phenomenon in syntax. It has been shown that parasitic gaps of the standard kind are licensed in quantificational A-bar environments (following Cinque's 1990 terminology). Even more relevant to the phenomena discussed here is Den Dikken's (2002) proposal that some NPIs can enter into a parasitic licensing relation. Den Dikken analyses a particular Dutch polarity item, the element heel 'whole'. This polarity item can occur in environments where it is directly licensed by the negative head $\mathrm{Neg}^{0}$, a case of standard licensing by spec-head agreement. In this situation, the element is licensed within the clause by the negative head $\mathrm{Neg}^{0}$ (49a). It must raise overtly to specNegP, and may then continue to a higher, topic-like position (49b):

a. Ik ken die hele vent niet.

I know that whole bloke not

'I don't know that bloke at all.'

b. ... dat ik die (hele) vent met niets gelukkig kan maken.

... that I that (whole) bloke with nothing happy can make

'that I can't make that bloke happy with anything at all.'

(Den Dikken 2002: (6a, 9a))

\footnotetext{
${ }^{33}$ Gécseg (2002) proposes that CT-marked constituents move to the left periphery to check a [+topic] and [+prominent] feature, a view I do not share, given the non-topic properties of CT (see also É. Kiss 2000).
} 
Den Dikken observes that the licensing of heel by $\mathrm{Neg}^{0}$ in these contexts is blocked by intervening negative elements (50):

a. Ik wil met die hele vent niet praten. heelPP-Neg-V

I want with that whole bloke not talk

'I don't want to talk to that bloke at all.'

b. *Ik wil niet met die hele vent praten.

I want not with that whole bloke talk

Neg-heelPP-V

(Den Dikken 2002: (26a, b))

Whereas in (50a), the heel PP-constituent is scrambled outside the c-command reach of niet, in (50b), the PP appears in-situ, and is thus c-commanded by the negative element.

In addition, the presence of this same heel can be grammatical even when direct licensing by $\mathrm{Neg}^{0}$ fails. Den Dikken observes that the licensing of heel may be rescued if the clause contains another, regularly licensed polarity item:

a. *Ik geloof niet dat ik die hele vent ken.

I believe not that I that whole bloke know

'I don't believe I know that bloke at all.'

b. Ik geloof niet dat ik die hele vent ooit gezien heb.

I believe not that I that whole bloke ever seen have

'I don't believe that I have ever seen that bloke at all.'

(Den Dikken 2002: (33b, 43b))

While the heel constituent cannot be licensed in an embedded CP which contains no sentential negation (51a), it is fine when the clause contains another, regularly licensed polarity item (ooit 'ever').

Den Dikken argues that heel is licensed under certain conditions, which are characteristic of parasitic licensing. First, there is the anti-c-command condition: the additional polarity item (the one which gets regularly licensed by Neg) must not ccommand the parasitic heel. Second, there is the connectedness requirement, in the spirit of Kayne (1984): the chain of the parasitic heel must connect to the chain of the regular polarity item. Thus, it can "piggy-back" on the neg-chain, which is regularly licensed. If the parasitic polar-heel chain is independent and fails to connect with the chain of the NPI licensed by the Neg head, it is not licensed. Finally, a third condition which enables to label heel licensing as parasitic licensing is the fact that the licensing must obtain before Spell-Out. Post Spell-Out checking of the neg features does not create the adequate licensing configuration for the parasitic heel. For a detailed discussion, the reader is referred to Den Dikken's paper.

It seems that our CT n-word is a perfect candidate for parasitic licensing. First, the head of the chain of the Pre-Neg n-word, senki 'nobody', does not c-command the parasitic semmelyik filmet 'no film'. This is in line with the anti-c-command condition. Second, Den Dikken's approach predicts that if connectedness fails, the parasitic element will not be licensed. This is the case in which the parasitic element is unable to link with the negative chain. Consider the following example: 

a. * $\sqrt{ }$ Egy színésznőnek semelyik ruháját
"senki
nem
an actress-DAT no
dress-POSS-ACC
n-person-NOM NEG

szerette.

liked-3s

'Nobody liked no dress of a particular actress.'

b. ? /Semelyik színésznő ruháját "senki nem

no actress-NOM dress-POSS-ACC n-person-NOM NEG

szerette.

likes-3S

'There is nobody who liked the dress of no actress.'

In (52a), the intended DN reading is not available. Interestingly, (52b) has at worst a slightly marginal status. ${ }^{34}$ The actual structure of a possessive DP appears to be much more complex than expected. It seems at least that whereas the peripheral possessor is able to c-command outside the possessive DP, the more embedded possessee cannot. ${ }^{35}$ It should be noted that in (52a) it is not the position of the n-word inside the DP as such which is at stake, since it can be licensed as a regular NC contributing n-word:

$$
\begin{aligned}
& \text { "Senki nem szerette egy színésznőnek "semelyik ruháját. } \\
& \text { n-person-NOM NEG liked-3S an actress-DAT no dress-ACC } \\
& \text { 'Nobody liked any dress of an actress.' }
\end{aligned}
$$

Given the observations above, I propose that the DN contributing n-word is a case of parasitic licensing. In this sense, the licensing of weak DN n-words is dependent on a primary negative relation not only semantically but also syntactically.

I now turn to the syntactic mechanism at the heart of the parasitic licensing. For ease of reference, I give below the relevant annotated example:

$$
\begin{aligned}
& \sqrt{ } \text { Semmiröl }_{\text {CT n-word }} \text { "senki } \text { Pre-Neg n-word }_{\text {nem beszélt. }} \\
& \text { n-thing-DELAT } \\
& \text { n-person-NOM NEG spoke-3S } \\
& \text { 'Nobody spoke about nothing.' }
\end{aligned}
$$

Recall that $\mathrm{n}$-words carry an uninterpretable Neg feature $u$ Neg. As in the previous case, the Pre-Neg n-word enters into Agree with the marker nem. The latter carries an interpretable feature $i \mathrm{Neg}$ and probes for a goal in its local domain. By Agree,

\footnotetext{
${ }^{34}$ Thanks to a reviewer for pointing this out to me. It may be worth mentioning that the same asymmetry holds in the parasitic heel constructions discussed in Den Dikken. Whereas pre-nominal possessors with parasitic heel are not licensed, post-nominal possessors are much better.

${ }^{35}$ The same reviewer notes that if the possessor in definite, we get a fully acceptable DN sentence:
}
(i) A színésznő semelyik ruháját "senki nem szerette. the actress-NOM a dress-ACC n-person-NOM NEG liked-3s
'Nobody like none of the dresses of the actress.'

Here, the possessor bears a nominative case, rather than a dative case, as in example (52a). The structure of the possessive DP in Hungarian is rather complex (see Szabolcsi 1983, 1994) and would require a more fine-grained analysis (see e.g. Knittel 1998). 
the uninterpretable feature of Pre-Neg n-word is checked. The result is a well-formed neg-chain. Given that there is no theoretical or empirical reason to postulate two different kinds of $\mathrm{n}$-words in Hungarian, I will propose that a CT n-word also carries an uninterpretable feature $u \mathrm{Neg}$. However, this n-word cannot enter into Agree with the Neg head, as it would in a standard NC context.

What is puzzling is that the lack of overt movement of the n-word entering into sentential negation fails to create the kind of neg-chain which licenses weak DN. (55) below cannot be interpreted as DN:

$$
\begin{aligned}
& \text { \# } \sqrt{ } \text { Semmiröl Zsolt nem beszélt senkivel. } \\
& \text { n-thing-DELAT Zsolt-NOM NEG spoke-3S n-person-INSTR }
\end{aligned}
$$

In fact, (55) cannot be interpreted at all. Obviously, as in the case of strong DN, the uninterpretable CT feature not only induces movement to spec CTopP, but somehow blocks the Agree relation with Neg. Thus, in (55), the n-word is not licensed as negative, and fails to be interpreted. As distinct from the Verum Focus operator, CT does not have any negative component, and hence does not carry a negative feature of any kind. The only possibility for the CT n-word to be licensed is to "piggy-back" on another negative chain, hence the parasitic nature of this licensing. As discussed above, such a parasitic licensing only obtains under certain conditions. The movement of semmiröl, the CT-n-word, to a left-peripheral position automatically provides the anti-c-command configuration. The overt movement of senki, the Pre-Neg n-word guarantees a pre-Spell-Out licensing. But I also claim, given (55), that the movement to the preverbal position of this n-word satisfies connectedness. In order for the primary neg-chain (formed by the negative marker and the n-word which appears in the Pre-Neg position) to be accessible, it must extend beyond the minimal domain of the negative marker, in the left periphery. By moving to the DistP position, the n-word extends the chain, and the CT-n-word can connect to it and be parasitically licensed by it. The parasitic licensing checks the uninterpretable feature on the n-word, but because it is checked in an indirect way, it cannot enter into NC with the elements of the primary neg-chain. Only a DN reading is available.

The (simplified) structure of a weak DN sentence is thus the following:

\footnotetext{
a. $\sqrt{ }$ Semmiröl $l_{\mathrm{CT}}$ n-word "senkiPre-Neg n-word nem beszélt. n-thing-DELAT n-person-NOM NEG spoke-3s

'Nobody spoke about nothing.'

b. [CTopP semmiröl [DistP senki [NegP nem beszélt [TP...[vP senki beszélt [VP beszélt semmirël ]]]]]]
}

Rather than postulating the introduction of another negative operator (see e.g. Zeijlstra 2004), I propose that the neg-chain itself turns into a licenser for the parasitic n-word. The movement of the two n-words to the pre-Neg and CT positions is independently motivated, as instances of feature checking. However, they create the configuration which enables parasitic licensing, and hence a dependent DN reading.

In this section, I have argued that the two kinds of DN result from two different semantic licensing mechanisms. Strong DN is associated with Polar Focus. The DN reading arises from the presence of an indefinite that is outside the scope of sentential negation. It is licensed by a VERUM $\mathrm{VEG}_{\mathrm{NEG}}$ operator. Syntactically, it is licensed 
by a Neg feature present on the null copula, which realizes the VERUM operator. Weak DN is associated with CT. I have argued that the n-word interpreted as a CT constituent is roofed by the sentential negation, but, because it is bound by the CT operator, it escapes the scope of sentential negation. Therefore, a CT constituent is dependent on a primary neg-chain while being outside its scopal reach. Syntactically, a CT constituent occurs in the left periphery, and is licensed by the primary neg-chain as a case of parasitic licensing.

In the next section, I discuss DN in English and German, and I will show that the two types of DN also occur in these languages. On the other hand, the specific properties of negation and of left-peripheral structure in these languages will impose different constraints on the licensing of the different types of DN.

\section{Questions about non-NC languages}

Let us now turn to English, a non-NC language. Most of the cases discussed in the literature involve the negative marker not, but DN readings also emerge in the absence of the negative marker:
a. John didn't say nothing.
b. Nobody said nothing.

Negative expressions have been described as intrinsically negative elements (see Zanuttini 1991; Haegeman 1995; Corblin and Tovena 2003 for discussion). Therefore, their licensing does not raise the same problems as those discussed for Hungarian, notably with respect to syntactic licensing.

Let us consider (57a) first. It is a typical case of strong DN, also discussed in the literature as metalinguistic negation (see e.g. Horn 1989; Carston 1994). The sentence is interpreted as a correction to a previous utterance of the type 'John said nothing'. As observed by Horn, the corrective flavor of the negation is even clearer if the negative marker is not in its contracted form:

\section{John did NOT say nothing.}

However, as discussed in the previous sections, I will consider the "metalinguistic" negation contribution as a result of semantic and syntactic properties of the construction. We can discriminate between the two negation contributing elements. In (58), the negative marker not is associated with a strong primary stress, which I take to be focal stress. Therefore, not is focused. It clearly contributes the DN. As for the n-word nothing, it conveys primary sentential negation on its own. Let us examine their respective contributions.

In the line of Zeijlstra (2004), I propose to reinterpret the claim that n-words are intrinsically negative in the following way: n-words carry an interpretable neg-feature $i \mathrm{Neg}$. As n-words do not need formal licensing in the form of feature checking, they can encode negation at the constituent level (and indeed they do not necessarily support sentential negation readings, see Haegeman 1995). But the question arises of how a sentence such as 'John said nothing' can be interpreted as sentential negation. Zeijlstra (2004) argues that languages like English do not have a sentential negation 
marker, and no Neg projection either. However, his approach does not account for the sentential negation reading of a sentence containing a negative expression in the object position. On the other hand, Haegeman (1995) claims that an English negative sentence contains an abstract Neg head. The role of this head is not to contribute negation, but to act as a sentential scope marker. Therefore, although the n-word is locally negative, the interpretation is sentential negation because by some mechanism (co-indexation in Haegeman), it reaches sentential scope. I will adopt a modified version of this proposal, and assume that the covert sentential negation marker bears an uninterpretable Neg feature $u$ Neg. Under the feature checking mechanism adopted here, this requires that the uninterpretable feature be checked via movement to the specifier position. This movement may be covert (feature movement) or overt, but crucially it enables the checking of the feature once and only once. Therefore, multiple occurrences of negative expressions will yield DN. ${ }^{36}$

As said above, DN arises when the sentence contains, in addition to the negative expression, the negative element not. The stress pattern suggests that not is focused. As in the case of Hungarian, Focus does not introduce a set of alternatives in this case. It is a Verum Focus. Following Höhle's original idea, I propose that the sentence contains a Verum operator which occupies $\mathrm{Foc}^{0}$, as was also discussed for Hungarian in Sect. 3.2 above. I propose that the focal stress signals the presence of the relevant (Verum) Focus feature, and that the negative element not raises covertly to FocP, where it has scope over the clause and negates it. ${ }^{37}$

Let us now turn to example (57b). Cases such as this one have, to my knowledge, attracted far less attention. They differ crucially from the (57a) type in that they do not involve the sentential negation marker not. As already mentioned in Sect. 2, there are two possible interpretations, linked to two different intonation patterns. The first one is the one I have labeled strong DN. In this case, the first n-word carries a heavy stress of the form $\mathrm{H}^{*} \mathrm{~L}$. The analysis can, to a large extent, correspond to the one given for sentence (57a) discussed above.

The weak DN reading, on the other hand, exhibits some interesting restrictions. While the pattern in (59a) is acceptable, the reverse intonation pattern is totally uninterpretable:
a. "None of the students liked $\sqrt{ }$ no film.
b. \# $\sqrt{ }$ None of the students liked "no film.

\footnotetext{
${ }^{36}$ Some authors have proposed that sentential negation is not necessarily a syntactic phenomenon. Thus in languages like English, the local negation gets interpreted as "sentential" since the n-word signals the negation of a participant in the event, which is then interpreted as negation of the event, and hence as sentential negation (see e.g. Tovena 1998). However, researchers who, like myself, believe in a close mapping between semantic and syntactic properties of the language may find it difficult to adhere to such a view.

${ }^{37}$ Although I have only discussed strong DN in the case of n-expression + not, it should by no means follow for the reader that the distinction between strong and weak $\mathrm{DN}$ boils down to the occurrence of one or several n-expressions. Rather, weak DN is predicted not to occur with one n-word, as it is parasitic on a negative chain, which minimally requires a negative marker and an n-expression. See also the discussion in Sect. 1. Many thanks to Marcel Den Dikken for pointing out this issue to me.
} 
These observations might appear as an unexpected counterargument to the CT analysis. In English, CT-marked constituents have been shown to appear in various positions, as illustrated in (60) below (from Büring 1999):

a. "Fred ate the $\sqrt{ }$ beans.

b. $\sqrt{ }$ Fred ate the "beans.

Whereas (non-negative) CT marking is possible both on the subject and object alike in (60), we observe this curious asymmetry in the case of negative constituents. I will argue that the contrast we observe in (59) actually confirms the secondary nature of weak DN. In order to get a better understanding of the problem, let us examine the partial representations for (59a) and (59b):

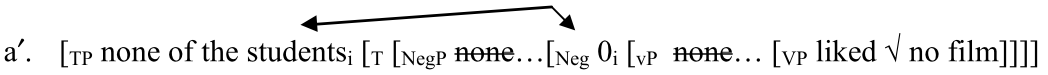

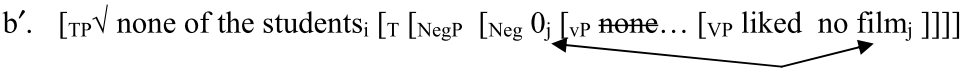

The primary neg-relation is given with the arrows in both cases. We observe that in $\left(59 \mathrm{a}^{\prime}\right)$ the primary chain is a chain obtained via overt movement. In other words, the primary chain obtains before Spell-Out. This contrast with $\left(59 b^{\prime}\right)$, where the primary chain, whatever its nature, is not a pre-Spell-Out chain. Recall that the same restriction was observed for Hungarian, where the DN contributing n-word was legitimate only if the primary neg-chain obtained before Spell-Out. This seems to be a strong constraint on the licensing of the parasitic type of DN.

As noted by a reviewer, this approach predicts a contrast in the pair of examples in (61) below. While (61a) is expected to be unavailable since it is structurally parallel to $\left(59 b^{\prime}\right),(61 b)$ "is expected to be OK, as the preposed n-word can pass through NegP in overt syntax on its way to the CP-domain". According to my informants, this is indeed the case:

a. $\quad \sqrt{ }$ No new film appeared in "none of the cinemas in town.

b. 'Never have I bought $\sqrt{ }$ nothing for your birthday.

On the other hand, English does not have overt CT movement. There are two theoretical options to account for the parasitic licensing. The first possibility is that what moves overtly is not the n-word as such, but only its relevant feature. Under an analysis of CT as a quantificational operator, it may be argued that the CT interpretation obtains via a chain formed with the CT operator. Alternatively, it may be that the licensing conditions are relaxed for English. Recall that the parasitic nature of the licensing was proposed in view of the nature of Hungarian n-words, namely their negative-dependency. DN is not strictly speaking a result of the licensing itself. It is the result of the combination of a negative element with a negative chain that encodes sentential negation. Since in English, the syntactic licensing is not crucially dependent on the Neg head (only the sentential negation interpretation is), an n-word may 
be licensed independently, provided that it does not enter the neg-chain. Such an option is not available anyway in English. Thus only discourse-functional requirements apply. However, the contrast between (59a) and (59b) suggests that some dependency is still necessary. I will propose that the dependency obtains via connectedness, and connectedness only. In order to be interpreted as a dependent negation, the n-word must connect to some negative chain, as shown by the contrast in (62) below. While a non-negative sentence may host a non-negative CT (62a), a negative CT is not licensed in the same environment (62b). Note that in the examples below, the diacritic ' signals an emphatic stress (see note 26 above):

a. Peter 'liked Jane ${ }_{C T}$.

b. *Peter 'liked none of the films $\mathrm{CT}$.

This connectedness requirement is satisfied in $\left(59 a^{\prime}\right)$ but not in $\left(59 b^{\prime}\right)$, given the assumption that a constituent marked as CT is licensed by a left-peripheral CT-Focus operator. Thus, the asymmetry we observe in (59) is an effect of the dependency requirement on weak $\mathrm{DN}$.

German data on DN comes as a remarkable confirmation of what we have observed and proposed for English. German is a non-NC language, which has a negative marker nicht similar to not. In the DN constructions involving nicht, we observe the same restriction to strong DN (confirmed also by the focal stress pattern associated with it): ${ }^{38}$
NIEMAND ist nicht gekommen.
nobody is not come
'Nobody didn't come.' (= Everybody came.)

However, German may also have DN, which involves several negative quantifiers. In this case, the characteristic $\mathrm{L} * \mathrm{H}$ pattern is available (in addition to the focal stress pattern, which is not illustrated here):

$$
\begin{aligned}
& \sqrt{ } \text { Mit niemandem habe ich über "nichts geredet. } \\
& \text { with nobody have I on nothing talked } \\
& \text { 'With nobody did I speak about nothing.' }
\end{aligned}
$$

Example (64) contains two n-words, mit niemandem 'with nobody' and über nichts 'on nothing'. Similarly to the English weak DN patterns discussed above, the intonational pattern illustrated in (64) is the only possible one. According to D. Büring (p.c.), the reverse pattern, with the $\mathrm{H}^{*} \mathrm{~L}$ accent on mit niemandem and the $\mathrm{L}^{*} \mathrm{H}$ on über nichts is not acceptable. Büring attributes this contrast to the fact that in German, the $\mathrm{L}^{*} \mathrm{H}$ (or contrastive topic) must precede the $\mathrm{H}^{*} \mathrm{~L}$ (focus) accent. Interestingly, the interpretation corresponds also to the kind of interpretation we have seen up to now, that is, (64) comes with alternatives that are not exclusively interpreted and triggers the implicature that 'there are some people with whom I talked about a little something' (D. Büring, p.c.).

${ }^{38}$ Thanks to Klaus Abels for pointing this out to me. 
I conclude that (64) is a case of weak DN, with an n-word in the CT position. The difference between German and English, though, lies in the fact that whereas in English, the left peripheral positions are extremely restricted, in German, the first position in V2 clauses may host either a Focus, or a Topic, or even a Contrastive Topic (see e.g. Molnár 1991). German has (a limited) overt access to the left periphery, a fact that enables an n-word to surface as a CT. That this structure yields a weak DN reading (see the implicature proposed above) confirms the analysis proposed here.

\section{Conclusion and further extensions}

In this paper, I have discussed the necessity to distinguish between two types of DN. Strong DN was shown to be the result of a Focus construction which involves a polar reading triggered by the Verum Focus. Weak DN, on the other hand, arises when the corresponding $\mathrm{n}$-word is a Contrastive Topic, a case of secondary focusing that introduces weak (i.e. non-exclusive) alternatives. I have examined the occurrence of these two types of DN in two types of languages, which feature different negative strategies. Hungarian is a strict NC language with non-negative n-words and an obligatory negative marker. $\mathrm{N}$-words are thus n-dependent elements, which need to be licensed by the negative marker nem. On the other hand, English and German are non-NC languages, with negative n-words that can function on their own. I have shown that both strong DN and weak DN occur in these languages. However, the mechanisms which license $n$-words contributing the $\mathrm{DN}$ reading are different, due to the differences in the nature of the n-words, and to the discourse-functional behavior of the languages. In Hungarian, all n-words require a negative licenser, which means that different levels of negation will come with different licensers. I have proposed that whereas an $\mathrm{n}$-word in a Focus position is licensed as an additional negation by a VERUM operator, an n-word in a CT position is licensed parasitically, on the existing negative chain. As Hungarian is also a language which displays a rich overt left periphery, the licensing mechanisms are overt. English n-words need no neg-licensing. I have however argued that to a certain extent, they can also contribute a weak DN reading. As they need not be licensed by a negative marker, they are not parasitic. But the restriction in the configurations led me to propose that the weak DN reading as dependent reading must nevertheless build on some dependency, a dependency I propose is syntactic and is expressed as connectedness. English does not have a rich overt left-peripheral domain and the discourse related operations of focusing and contrastive topicalization apply covertly. On the other hand, German is able to use some left-peripheral position, and we observe overt CT. We have thus seen that to the extent that an n-word can satisfy both the discourse-functional conditions on the different DN types and the syntactic licensing requirements, DN obtains in its various forms.

Languages may be a mix of the two types discussed in this paper. French is such a language, with on the one hand a pure constituent negation marker pas and on the other hand n-words that need to be chain-related to the negative marker ne and can enter NC. While pas functions like English not, it seems that n-words display some of the properties of Hungarian (NC, a licensing mechanism which seems to involve the marker ne). French also has DN manifestations of both types, but with restrictions. There is still a certain amount of controversy on the nature of n-words (see e.g. 
Déprez 2003; Mathieu 2001, for different views) as well as on the status of the marker $n e$ (Péters 2001; Rooryck 2008). However, DN also occurs in this language, both in what I have labeled its strong form, involving Focus (see Puskás 2009) and, to some extent, in its weak form. This latter domain is still in need of deeper investigation (but see De Swart and Sag 2002 for a discussion of DN in French).

In the course of this research, many questions had to be addressed, bearing on the status of n-words in different languages and their relation to overt negative markers, on the structure of Focus sentences and on the analysis of overt and covert movement. The status of n-words is still at the heart of various debates, as can be seen from the rich literature in this field. Peripheral questions also inevitably arise, such as the question of the structure of negative sentences in Hungarian and of the position of the verb in these sentences. The question of the syntax of Focus is also re-examined, since a rich comparative literature has brought to the fore the striking similarities-beyond surface differences - exhibited by the interaction between Focus and negation in an impressive number of unrelated languages. The theoretical question of overt/covert, feature/operator movement is also at the heart of much of the recent research in generative syntax. This paper cannot answer all these questions, and some shortcuts and assumptions have proven necessary so as to keep our objective in the target line. Most of these questions turn out to be under investigation in on-going personal research and considering them in the light of negation offers a new handle on them. I can only hope readers find material here to feed their own investigations.

On the surface, it may seem that some of the issues, such as the triggering of alternatives or the metalinguistic nature of the DN phenomena, are external to and somewhat independent from strict semantic or syntactic licensing conditions of n-words. However, as was shown here, the semantic conditions (licensing by negative or Verum operators) and the syntactic conditions (moving overtly or covertly to a unique structural Identificational Focus position or to nested focus positions involving a CT-Focus) determine not only the organization of the information structure, but also the availability of alternatives. There is still debate as to the strict relation between the syntax-semantics properties and pragmatic effects such as the triggering of implicatures. I hope that this study may also provide, beyond the questions on negation and the status of negative elements, some reflection on the real nature of the interface not only between semantics and syntax, but also between syntax and pragmatics.

Acknowledgements I wish to thank the three anonymous reviewers for their extremely careful and detailed reading, their valuable comments and suggestions. I also wish to address my warmest thanks to Marcel den Dikken for his careful reading, his many suggestions and positive input. Many thanks also to Lena Baunaz, Daniel Büring, Anna Cardinaletti, Donka Farkas, Liliane Haegeman, Terje Lohndal, Valeria Molnár, Chris Piñón, Maribel Romero, Michal Starke, Lisa Travis, Susanne Winkler, Hedde Zeijlstra, and audiences in Troms $\varnothing$, Montreal, Lund, Geneva, Tampa, and Wroclaw for comments and suggestions. All remaining errors can only be attributed to my own stubbornness.

\section{References}

Baunaz, Lena. 2008. Split-DP and floating quantifiers: A syntactic approach to French Quantification. PhD dissertation, University of Geneva, Geneva. 
Belletti, Adriana. 1990. Generalized verb movement. Torino: Rosenberg \& Sellier.

Bolinger, Dwight. 1965. Pitch accent and sentence rhythm. In Forms of English: Accent, morpheme, order, eds. Isamu Abe and Tetsuya Keneyiko. Cambridge: Harvard University Press.

Bošković, Željko. 2007. On the locality and motivation of Move and Agree: an even more minimal theory. Linguistic Inquiry 38: 589-644.

Brody, Michael. 1990. Some remarks on the Focus Field in Hungarian. UCL Working Papers 2: 201-225.

Büring, Daniel. 1999. On D-trees, beans and B-accents. Ms., University of California, Santa Cruz.

Carston, Robyn. 1994. Metalinguistic negation and echoic use. UCL Working Papers in Linguistics 6: 321-349.

Chomsky, Noam. 1995. The minimalist program. Cambridge: MIT Press.

Cinque, Guglielmo. 1990. Types of A-bar dependencies. Cambridge: MIT Press.

Corblin, Francis. 1996. Multiple negation processing in natural language. Theoria 62: 214-260.

Corblin, Francis, and Lucia Tovena. 2003. L'expression de la négation dans les langues romanes. In Les langues romanes: problèmes de la phrase simple, ed. Danièle Godard, 242-279. Paris: CNRS Editions.

Den Dikken, Marcel. 2002. Direct and parasitic polarity item licensing. The Journal of Comparative Germanic Linguistics 5(1): 35-66.

Déprez, Viviane. 2003. Concordance négative, syntaxe des mots-N et variation dialectale. Cahier de Linguistique Francaise 25: 97-118.

Ducrot, Oswald. 1972. Dire et ne pas dire: principes de sémantique linguistique. Paris: Hermann.

É. Kiss, Katalin. 1987. Configurationality in Hungarian. Dordrecht: Reidel.

É. Kiss, Katalin. 1998. Identificational focus versus information focus. Language 74: 245-273.

É. Kiss, Katalin. 2000. A [+referáló] és [+specifikus] jegyek ellenőrzése a kontrásztív topik esetében [the checking of the features [+referential] and [+specific] in the case of contrastive topic]. In $A$ mai magyar nyelvleírásának újjabb módszerei IV [New Methods in the Description of Hungarian IV], eds. László Büky and Márta Maleczki, pp. 85-96. Szeged: University of Szeged Press.

É. Kiss, Katalin. 2002. The syntax of Hungarian. Cambridge: Cambridge University Press.

Gécseg, Zsuzsanna. 2002. A kontrasztív topik szintaxisárol és szemantikájárol [on the syntax and semantics of contrastive topics]. Magyar Nyelv XCVII 3:283-293 and 4:423-431

Giannakidou, Anastasia. 1998. Polarity sensitivity as nonveridical dependency. Amsterdam: Benjamins.

Giannakidou, Anastasia. 2000. Negative ... concord? Natural Language \& Linguistic Theory 18: 457523.

Gyuris, Beáta. 2002. The semantics of contrastive topics in Hungarian. PhD dissertation, Eötvös Loránd University, Budapest.

Haegeman, Liliane. 1995. The syntax of negation. Cambridge: Cambridge University Press.

Haegeman, Liliane, and Rafaella Zanuttini. 1996. Negative concord in West Flemish. In Parameters and functional heads: Essays in comparative syntax, eds. Adriana Belletti and Luigi Rizzi, 117-179. Oxford: Oxford University Press.

Höhle, Tilman N.. 1992. Über Verum-Fokus im Deutschen. In Informationsstruktur und Grammatik: Sonderheft 4, Linguistische Berichte, ed. Joachim Jacobs, 112-141. Opladen: Westdeutscher Verlag.

Horn, Laurence. 1989. A natural history of negation. Chicago: University of Chicago Press.

Horn, Laurence. 1991. Duplex negatio affirmat. . . : the economy of double negation. In Papers from the 27 th regional meeting of the Chicago Linguistic Society, eds. Lise Dobrin, Lynn Nichols, and Rosa M. Rodriguez, 80-106. Chicago: Chicago Linguistic Society.

Horváth, Julia. 1986. FOCUS in the theory of grammar and the syntax of Hungarian. Dordrecht: Foris.

Jackendoff, Ray. 1972. Semantic interpretation in generative grammar. Cambridge: MIT Press.

Jacobs, Joachim. 1996. Bemerkungen zur I-Topikalisierung [Remarks on I-topicalisation]. Sprache und Pragmatik 41: 1-48.

Jespersen, Otto. 1924. The philosophy of grammar. London: Allen \& Urwin.

Kálmán, László, and Ádám Nádasdy. 1994. A hangsúly [stress]. In Strukturális Magyar Nyelvtan 2: Fonológia [A structural grammar of Hungarian 2: Phonology], ed. Ferenc Kiefer, 393-467. Budapest: Akadémiai Kiadó.

Karagjosova, Elena. 2006. Correction and acceptance by contrastive focus. In Brandial '06: Proceedings of the 10th workshop on the semantics and pragmatics of dialogue, Potsdam, Germany, 11-13 September, eds. David Schlangen and Raquel Fernández, 26-33. Potsdam: University of Potsdam.

Kayne, Richard. 1984. Connectedness and binary branching. Dordrecht: Foris.

Kenesei, István. 1986. On the logic of word-order in Hungarian. In Topic, focus and configurationality, eds. Werner Abraham and Sjaak de Meij, 143-159. Amsterdam: Benjamins. 
Kenesei, István. 2006. Focus as identification. In The architecture of focus: Studies in generative grammar 82 , eds. Valéria Molnár and Susanne Winkler, 137-168. Berlin: de Gruyter.

Knittel, Marie-Laurence. 1998. Structure morphosyntaxique des syntagmes nominaux possessivés du hongrois. In La grammaire de la possession, eds. Jacqueline Guéron and Anne Zribi-Hertz, 128-183. Nanterre: Presses Universitaires de Paris 10.

Kratzer, Angelika. 1991. The representation of focus. In Semantics: An international handbook of contemporary research, eds. Arnim von Stechow and Dieter Wunderlich, 825-834. Berlin: de Gruyter.

Krifka, Manfred. 1991. A compositional semantics for multiple focus constructions. Proceedings of Semantics and Linguistic Theory 1: 127-158.

Ladusaw, William. 1992. Expressing negation. In Proceedings of the conference on semantics and linguistic theory, 2, 237-259. Columbus: Ohio State University Press.

Laka, Itziar. 1990. Negation in syntax: on the nature of functional categories and projections. PhD dissertation, MIT.

Lambrecht, Knud. 1994. Information structure and sentence form. Cambridge: Cambridge University Press.

Lee, Young-Suk, and Laurence R. Horn. 1994. Any as indefinite plus even. Ms., Yale University, New Haven, CT.

Lee, Chungmin. 1999. Contrastive topic, a locus of the interface: Evidence from Korean and English. In The semantics/pragmatics interface from different points of view: Current research in the semantics/pragmatics interface 1, ed. Ken Turner. Oxford: Elsevier.

Lee, Chungmin. 2003. Contrastive topic and/or contrastive focus. In Japanese/Korean Linguistics 12, ed. William McClure. Stanford: CSLI.

Lee, Chungmin. 2006. Contrastive (predicate) topic, intonation, and scalar meanings. In Topic and focus: Meaning and intonation from a crosslinguistic perspective, eds. Chungmin Lee, Matthew Gordon, and Daniel Büring, 151-175. Dordrecht: Kluwer Academic.

Maleczki, Márta. 2003. Information structure, argument structure and typological variation. In Meaning through language contrast, eds. Katarzyna Jaszczolt and Ken Turner, 223-244. Amsterdam: Benjamins.

Mathieu, Eric. 2001. On the nature of French n-words. UCL Working Papers in Linguistics 13: 319-352.

Molnár, Valéria. 1991. Das Topik im Deutschen und im Ungarischen [Topic in German and in Hungarian]. Lund: Almqvist \& Wiksell.

Molnár, Valéria. 1998. Topic in Focus. On the syntax, phonology and pragmatics of the so-called "contrastive topic" in Hungarian and German. Acta Linguistica Hungarica 45: 89-166.

Olsvay, Csaba. 2000. Negative universal quantifiers in Hungarian. A syntactic analysis of negative universal quantifiers in Hungarian. MA thesis, Eötvös Loránd University.

Olsvay, Csaba. 2006. Negative universal quantifiers in Hungarian. Lingua 116: 245-271.

Péters, Hugues. 2001. Raising and negative quantification in French. Generative Grammar in Geneva 2: 71-86.

Pesetsky, David, and Esther Torrego. 2007. The syntax of valuation and the interpretability of features. In Phrasal and clausal architecture: Syntactic derivation and interpretation. In honor of Joseph E. Emonds, eds. Simin Karimi, Vida Samiian, and Wendy K. Wilkins, 262-294. Amsterdam: Benjamins.

Puskás, Genoveva. 1994. Sentential negation in Hungarian. Rivista di Linguistica 6: 57-90.

Puskás, Genoveva. 1998. On the neg-criterion in Hungarian. Acta Linguistica Hungarica 45(1-2): 167213.

Puskás, Genoveva. 1999. Negation and n-words in Hungarian. In Proceedings of the twenty-eighth western conference on linguistics, eds. Nancy Antrim, Grant Goodall, Martha Shulte-Nafeh, and Vida Samiian, 443-456. Fresno: California State University.

Puskás, Genoveva. 2000. Word order in Hungarian: The syntax of A-bar positions. Amsterdam/Philadelphia: Benjamins.

Puskás, Genoveva. 2002. On negative licensing contexts and the role of n-words. In Approaches to Hungarian 8: Papers from the Budapest conference, eds. István Kenesei and Péter Siptár, 81-106. Budapest: Akadémiai Kiadó.

Puskás, Genoveva. 2006. Double negation and information structure: somewhere between topic and focus. In The Architecture of Focus, eds. Valéria Molnár and Susanne Winkler, 291-317. Berlin/New York: de Gruyter.

Puskás, Genoveva. 2009. De l'interaction entre structure informationnelle et syntaxe: quelques réflexions sur la double négation en français. In Mélanges plurilingues offerts à Suzanne Schlyter à l'Occasion 
de son 65ème anniversaire, eds. Petra Bernardini, Verner Egerland, and Jonas Granfeldt, 273-287. Lund: Lunds Universiteit.

Rizzi, Luigi. 1997. The fine structure of the left periphery. In Elements of grammar, ed. Liliane Haegeman, 281-337. Dordrecht: Kluwer Academic.

Rizzi, L.. 2004. On the form of chains: criterial positions and ECP effects. Ms., University of Sienna.

Romero, M., and C.-H. Han. 2002. Verum focus in negative Yes/No questions and Ladd's p/nonp ambiguity. In Proceedings of semantics and linguistic theory (SALT) 11, ed. Brendan Jackson, 204-224. Ithaca: CLC Publications.

Rooryck, Johan. 2008. On the scalar nature of syntactic negation in French. Paper presented at the Research Seminar, Linguistics Department, University of Geneva.

Rooth, Mats. 1985. Association with focus. Ph.D. dissertation, University of Massachusetts, Amherst.

Rooth, Mats. 1992. A theory of focus interpretation. Natural Language Semantics 1: 75-116.

von Stechow, Arnim. 1991. Current issues in the theory of focus. In Semantics: An international handbook of contemporary research, eds. Amim von Stechow and Dieter Wunderlich, 804-825. Berlin: Gruyter.

Surányi, Balázs. 2002. Negation and the negativity of n-words in Hungarian. In Approaches to Hungarian 8: Papers from the Budapest conference, eds. István Kenesei and Péter Siptár, 107-132. Budapest: Akadémiai Kiadó.

Surányi, Balázs. 2003. Multiple operator movements in Hungarian. Utrecht: University of Utrecht.

Surányi, Balázs. 2006. Quantification and focus in negative concord. Lingua 116: 272-313.

de Swart, Henriëtte. 2010. Expression and interpretation of negation. An OT typology. Dordrecht: Springer.

de Swart, Henriëtte, and Ivan A. Sag. 2002. Negation and negative concord in Romance. Linguistics and Philosophy 25: 373-417.

Szabolcsi, Anna. 1981. Compositionality in focus. Folia Linguistica 15: 141-161.

Szabolcsi, Anna. 1983. The possessor that ran away from home. The Linguistic Review 3: 89-102.

Szabolcsi, Anna. 1994. The noun phrase. In Syntax and semantics 27: The syntactic structure of Hungarian, eds. Ferenc Kiefer and Katalin É. Kiss, 179-274. San Diego: Academic Press.

Szabolcsi, Anna. 1997. Strategies for scope taking. In Ways of scope taking, ed. A. Szabolcsi, 109-154. Dordrecht: Foris.

Tomioka, Satoshi. 2009. Contrastive topics operate on speech acts. In Information structure: theoretical, typological, and experiment perspectives, eds. Malte Zimmermann and Caroline Féry. Oxford: Oxford University Press.

Tóth, Ildikó. 1995. Negative Polarity licensing in Hungarian. MA Thesis, Szeged, Hungary: József Attila University.

Tovena, Lucia. 1998. The fine structure of polarity sensitivity. London: Garland.

Wagner, Michael. 2008. A compositional analysis of contrastive topics. In Proceedings of NELS 38, eds. Muhammad Abdurrahman, Anisa Schardl, and Martin Walkow, 1-14.

Watanabe, Akira. 2004. The genesis of negative concord: syntax and morphology of negative doubling. Linguistic Inquiry 35: 559-612.

Yabushita, Katsuhiko. 2008. A new approach to contrastive topic: Partition semantics and pragmatics. In Proceedings of semantics and linguistic theory (SALT) 18, 747-764. Berlin: Springer.

Zanuttini, Rafaella. 1991. Syntactic properties of sentential negation: a comparative study of Romance languages. Dissertation, University of Pennsylvania, Philadelphia, PA.

Zanuttini, Rafaella. 1997. Negation and clausal structure: A comparative study of Romance languages. Oxford: Oxford University Press.

Zeijlstra, Hedde H.. 2004. Sentential negation and negative concord. PhD Dissertation, University of Amsterdam. Utrecht: LOT Publications.

Zeijlstra, Hedde H.. 2010. There is only one way to Agree. Paper presented at the 33rd generative linguistics in the Old World conference (GLOW 33), Wroclaw, April 2010. 